\title{
10. BIOSTRATIGRAPHY AND SYSTEMATIC DESCRIPTION OF BENTHIC FORAMINIFERS FROM MID-CRETACEOUS SHALLOW-WATER CARBONATE PLATFORM SEDIMENTS AT SITES 878 AND 879 (MIT AND TAKUYO-DAISAN GUYOTS) ${ }^{1}$
}

\author{
Annie Arnaud Vanneau ${ }^{2}$ and Isabella Premoli Silva ${ }^{3}$
}

\begin{abstract}
Fourteen species of benthic foraminifers from Aptian and Albian shallow-water carbonates covering MIT and Takuyo-Daisan Guyots are identified and a new species, Cuneolina sliteri, is described. Carbonate platform microfaunas are subdivided into seven benthic foraminifer assemblages. On MIT Guyot, there is a 700-m-thick, probably complete section of Aptian-Albian, but the latest Albian faunal assemblage (Assemblage 0) is missing, indicating that platform growth ceased probably earlier at MIT than on the Takuyo-Daisan carbonate platform. On the other hand, the carbonate cover of Takuyo-Daisan Guyot is thinner (around 200 $\mathrm{m}$ ), and a part of the Albian sequence is probably missing. Carbonate environments are extended from open-marine and waveexposed deposits to lagoonal and restricted environments. Rising sea level is indicated by the presence of abundant orbitolinids in lagoonal settings.
\end{abstract}

\section{INTRODUCTION}

MIT Guyot (Site 878) and Takuyo-Daisan Guyot (Site 879) are located close to the Wake Group and in the Japanese Group, respectively (see site map preceding the title page). The location of drilling sites during Leg 144 was proposed to determine the history of Cretaceous volcanism, subsidence, sea-level changes, and carbonate platform development.

Site 878 is located at $27^{\circ} 19.143^{\prime} \mathrm{N}, 151^{\circ} 53.028^{\prime} \mathrm{E}$, in a water depth of $1323 \mathrm{~m}$, on the northeastern part of MIT Guyot and near its edge. Some $720 \mathrm{~m}$ of Cretaceous shallow-water limestone resting on basalt was drilled at Hole $878 \mathrm{~A}$ and has been divided into three major lithologic subunits. The lower carbonate platform unit (from Sections 144-878A-78R-1, $44 \mathrm{~cm}$, to -65R-6, $23 \mathrm{~cm}$ ) is Aptian, the volcanic breccia and limestone clast unit (from Sections 144-878A-65R-6, 23 $\mathrm{cm}$, to $-43 \mathrm{M}-1,43 \mathrm{~cm}$ ) is upper Aptian, and the upper carbonate platform unit (from Sections 144-878A-43M-1, $43 \mathrm{~cm}$, to - $1 \mathrm{R}-\mathrm{CC}, 0$ $\mathrm{cm}$ ) is upper Aptian to upper Albian.

Site 879 is located at $34^{\circ} 10.46^{\prime} \mathrm{N}, 144^{\circ} 18.56^{\prime} \mathrm{E}$, in a water depth of $1501 \mathrm{~m}$, on top of the southern ridge of the Takuyo-Daisan Guyot. One objective of this site was to determine the existence of a barrier reef on the edge of the atoll. About $200 \mathrm{~m}$ of Cretaceous shallowwater limestone, ranging in age from late Aptian to late Albian, was drilled before encountering basalt, but recovery was poor and there was no recovery between around 50 and $80 \mathrm{~m}$.

The biostratigraphy of the Cretaceous shallow-water carbonates recovered from Leg 144 is based on both benthic foraminifers and on planktonic foraminifers and calcareous nannofossils recovered from a few levels (see Erba et al., this volume). Calcareous algae are a minor biostratigraphic component of the fossil assemblage from Leg 144 , but their occurrence provides additional age information that confirms the age determinations from other fossil group (see Masse and Arnaud Vanneau, this volume).

\footnotetext{
${ }^{1}$ Haggerty, J.A., Premoli Silva, L., Rack, F., and McNutt, M.K. (Eds.), 1995. Proc. $O D P$, Sci. Results, 144: College Station, TX (Ocean Drilling Program).

${ }^{2}$ Institut Dolomieu, Laboratoire de Géodynamique des Chaînes Alpines, 15 rue Maurice Gignoux, 38031 Grenoble Cedex, France.

${ }^{3}$ Dipartimento di Scienze della Terra, Università di Milano, Via Mangiagalli 34, 20133 Milano, Italy.
}

An exhaustive study of the most important Cretaceous benthic foraminifers was prepared for Leg 143 (Arnaud Vanneau and Sliter, 1995), but benthic foraminifers are surprisingly different for Leg 144 . The Aptian to Albian section at MIT Guyot is probably one of the most complete sequences from the interval drilled during the two legs, and the youngest platform assemblage at Takuyo-Daisan Guyot (Site 879) was not recovered from the other drilled sites. Correlation between all Cretaceous sites drilled during Leg 143 and 144 and their biostratigraphy will be published later in a synthesis paper by $\mathrm{A}$. Arnaud Vanneau and W.V. Sliter (unpubl. data).

\section{METHODS}

About 300 samples from Leg 144 were examined in thin section. In addition, specimens were isolated from limestone using a complex technique that involves impregnation of the limestone samples with sodium sulfate in a vacuum bell jar and successive freezing and heating episodes in a thermocryostat (Argot, in press). The free specimens were examined in oriented thin sections or as whole specimens.

In most cases, samples were selected randomly from the cored interval or at specific levels based on microscopic examination of the core. The stratigraphic distribution of foraminifers and algae are shown in Tables 1 and 2 . Their abundance is indicated by the following abbreviations:

VA (very abundant): $>10$ for large foraminifers and $>20$ for small foraminifers;

A (abundant): 6-10 for large foraminifers and 10-20 for small foraminifers:

C (common): $3-5$ for large foraminifers and 3-10 for small foraminifers;

F (few): 2 specimens for both large and small foraminifers; and $\mathrm{R}$ (rare): single specimen for both large and small foraminifers.

The ecological distribution of foraminifers, algae, and fragments of metazoans are shown in Tables 3 and 4.

Sample notation follows the standard ODP format, that is, drilling leg number followed by hole number, core number and core type letter (e.g., $\mathrm{R}=$ rotary), section number, and interval (given in centimeters below the top of the section). The abbreviation "CC" refers to a core-catcher sample taken from the bottom of the cored interval.

The stratigraphic distribution of foraminifers is shown in Figures 1 and 2 . 
Table 1. Stratigraphic distribution of Cretaceous benthic foraminifers, Hole 878A (MIT Guyot).

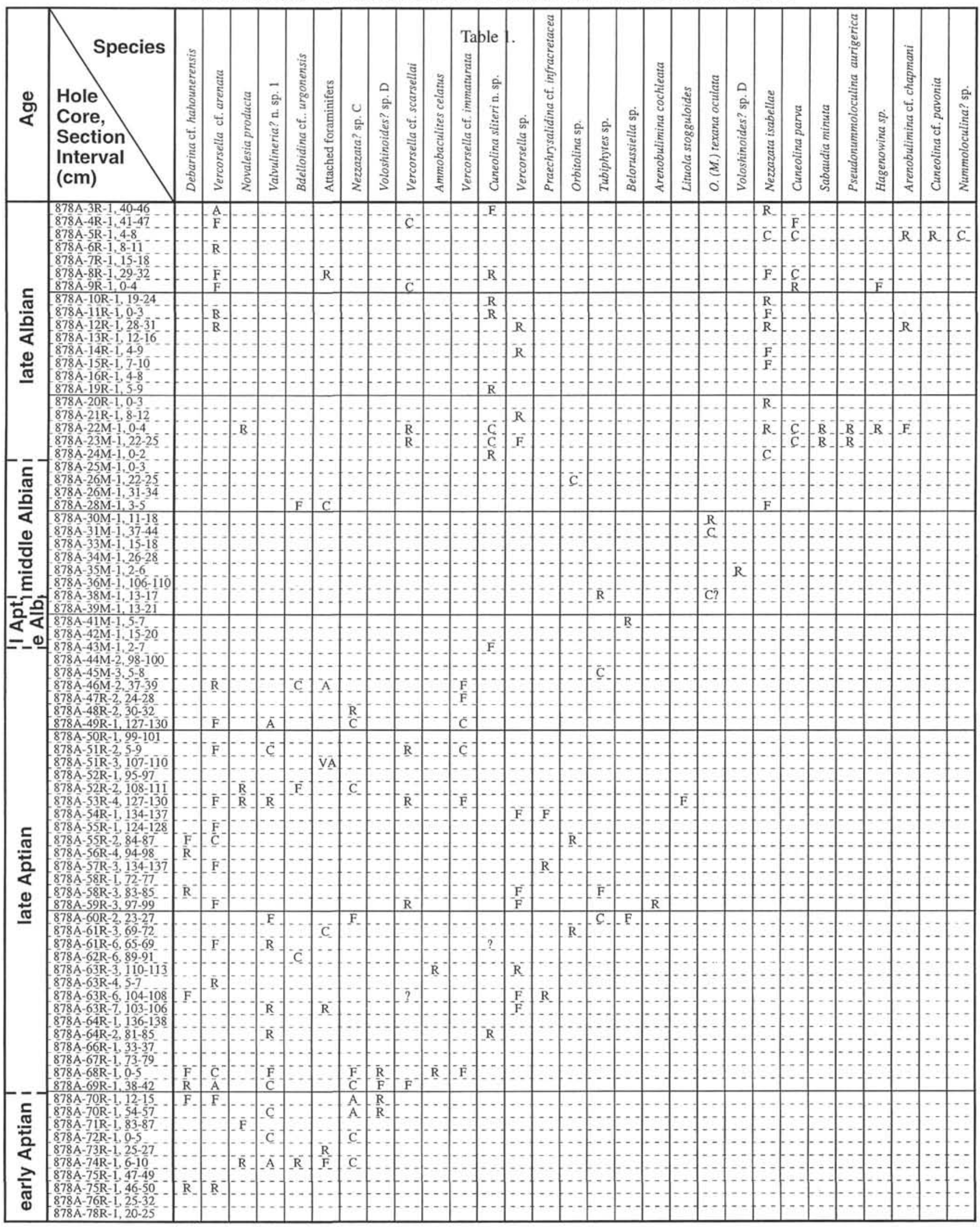




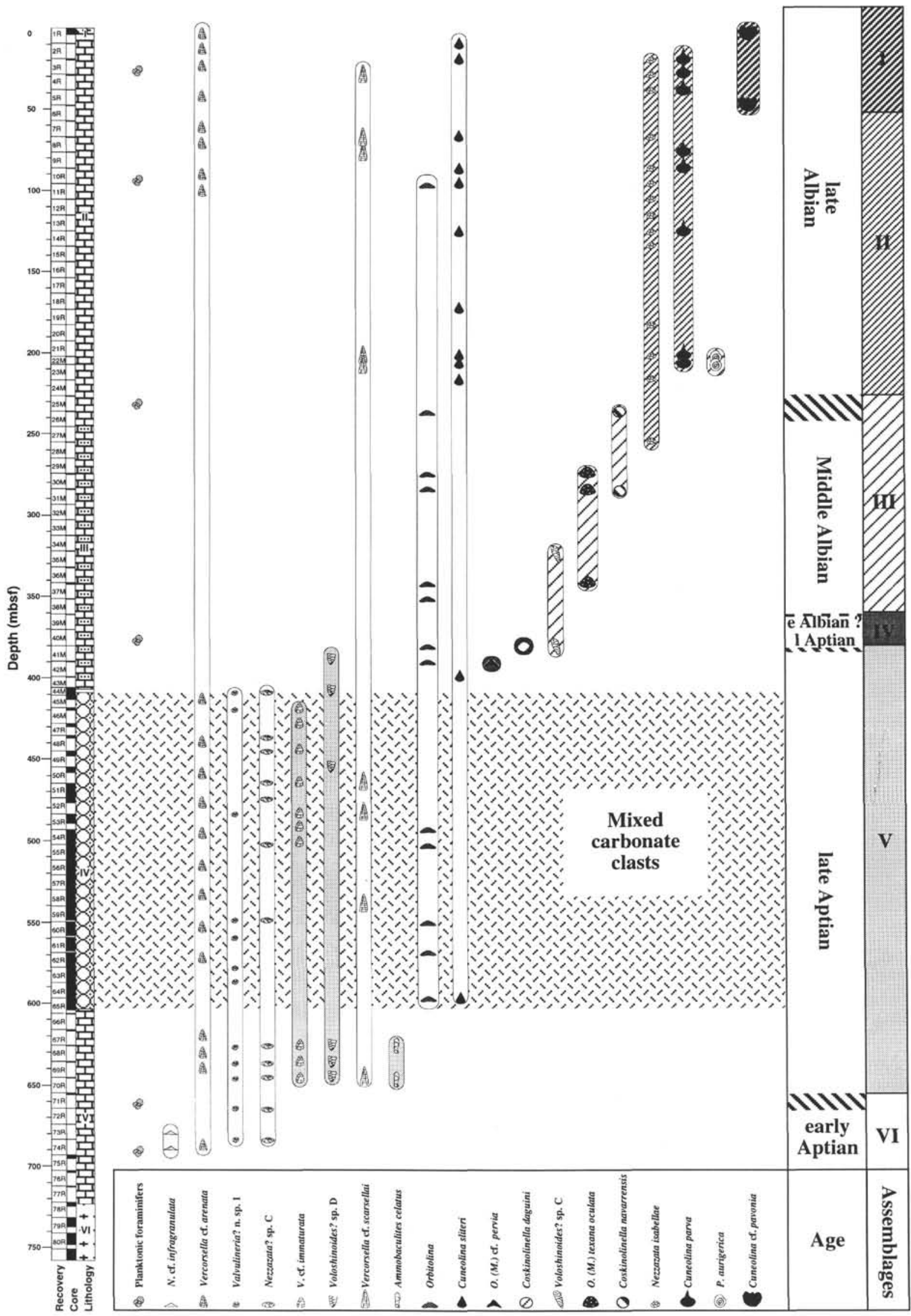

Figure 1. Distribution of the most important Cretaceous benthic foraminifers from Hole 878A. 


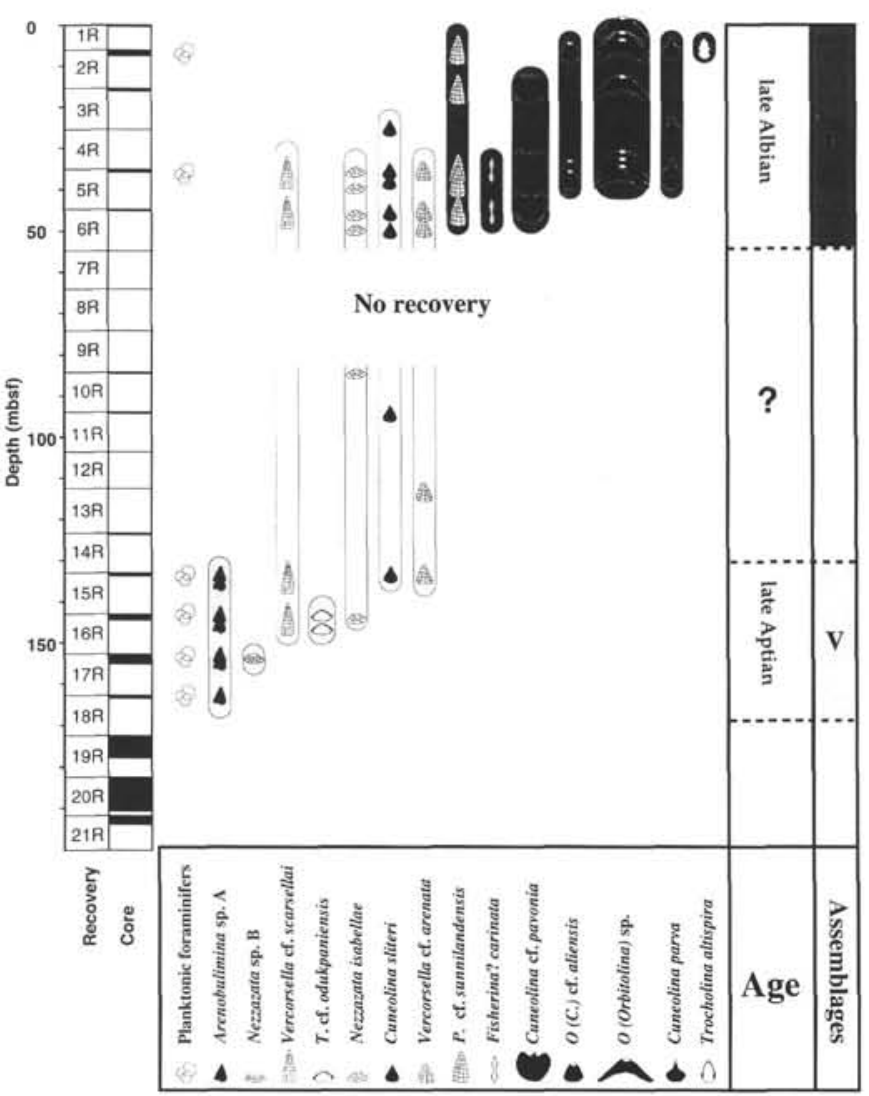

Figure 2. Distribution of the most important Cretaceous benthic foraminifers from Hole 879A.

\section{PREVIOUS PACIFIC RECORD}

Arnaud Vanneau and Sliter (1995) discussed the Cretaceous age of many guyots established by workers since 1956 (including Hamilton, 1956) on Hess and Cape Johnson guyots.

For micropaleontological data, the most interesting results were published from Daiichi-Kashima Seamount (Research Group for the Daiichi-Kashima Seamount, 1976; Shiba, 1988; Konishi, 1989) and Yabe Guyot (Shiba, 1979), or from the topmost dredge samples from Charlie Johnson, Isakov, MIT, Woods Hole, and Allison guyots (Schlager and Philip, 1990; Grötsch, 1991; Grötsch and Flügel, 1992), which yielded an Albian age.

\section{BIOSTRATIGRAPHIC ZONATION}

The biostratigraphy used to date the succession of Early-mid Cretaceous benthic foraminifers from Leg 144 is based primarily on the results of the Working Group on Benthic Foraminifera, IGCP Project No. 262, "Tethyan Cretaceous Correlation," chaired by A. Arnaud Vanneau and on previous European publication (Schroeder and Neumann, 1985). An unpublished stratigraphic distribution chart that summarizes the results was prepared by some 40 specialists from 14 countries. This collaboration clarified the stratigraphic distribution of the most important age-diagnostic benthic foraminifers from a broad geographic area, which includes the northern margin of the Tethys and the southern margin from the Middle East to Morocco and the Adriatic area from Greece, Albania, Croatia, Slovenia, and Italy.

\section{SYSTEMATIC DESCRIPTION}

The most biostratigraphically important Cretaceous benthic foraminifers of MIT (Site 878) and Takuyo-Daisan (Site 879) guyots are discussed and illustrated. The synonymic list for each taxon is reduced to the original description of each species, followed by the principal revisions and previous references in the Pacific area. For the most part, we have followed the classification of Loeblich and Tappan (1988), to which readers should refer for authorships of taxonomic categories higher than species level.

\section{Order FORAMINIFERIDA Eichwald, 1830 \\ Family HAPLOPHRAGMOIDIDAE Maync, 1952 \\ Genus Debarina Fourcade et al., 1972 \\ Debarina sp. cf. D. hahounerensis Fourcade, Raoult and Vila, 1972} (P1. 1, Figs. 1, 2)

Description. Test planispiral, partially involute, slightly compressed. Protoconch small, globular, followed by 3 or 4 whorls of subrectangular chambers in axial section, with up to 12 chambers per whorl. Plane of coiling in initial whorl is more or less perpendicular to the plane of subsequent whorls (Pl. 1, Fig. 2). Wall calcareous, microgranular. Aperture a row of rounded pores at base of apertural face (PI. 1, Fig. 2).

Remarks. About 30 specimens were observed in thin section. These Pacific forms are smaller and more compressed than the type specimens of Debarina hahounerensis.

Age and occurrence. Aptian to early Albian; MIT Guyot from Sections 144-878A-53R-3 to -75R-1; Takuyo-Daisan Guyot from Sections 144-879A$5 \mathrm{R}-1$ to $-16 \mathrm{R}-1$

Known range. late Barremian to Albian

Geographic distribution. Originally described from the Aptian of Algeria, this species is widespread along the margins of the Tethys.

\section{Family MAYNCINIDAE Loeblich and Tappan, 1985} Genus Daxia Cuvillier and Szakall, 1949

Daxia sp. cf. D. minima Laug and Peybernès, 1979

$$
\text { (Pl. 1, Fig. 3) }
$$

Description. Test lenticular and flattened, planispiral, involute with numerous broad, low chambers per whorl. Wall agglutinated, simple. Aperture areal, at base of apertural face.

Remarks. Four specimens were observed in thin section. The Pacific specimens are larger than the type specimen.

Age and occurrence. late Aptian to late Albian; MIT Guyot from Samples 144-878A-14R-1, 4-9 cm, and -18R-1, 40-43 cm; Takuyo-Daisan Guyot from Samples 144-879A-14R-1, 8-13 cm, and -16R-1, 27-33 cm

Known range. Berriasian to Albian

Geographic distribution. This species is known from the two margins of the Tethys and was originally described from Aptian sediments of southwestern France.

\section{Family LITUOLIDAE De Blainville, 1827 \\ Genus Ammobaculites Cushman, 1910}

Ammobaculites celatus Arnaud Vanneau, 1980

(Pl. 1, Fig. 6)

Ammobaculites celatus Arnaud Vanneau, 1980, pp. 320-325, pl. 63, figs. 8-9; text-figs. 107-109

Description. Test elongate, early stage with a short coil made by a rounded protoconch and two chambers, later uncoiling and rectilinear with oblique sutures. Wall coarsely agglutinated, calcareous. Aperture rounded, terminal, alternating from one side to the other.

Age and occurrence. Aptian (early to late? Aptian); MIT Guyot from Samples 144-878A-68R-1, 0-5 cm, and -70R-1, 11-15 cm

Known range. early Aptian

Geographic distribution. This species is known from the lower Aptian of the French Alps.

Genus Lituola Lamark, 1804

Lituola strogguloides Arnaud Vanneau, 1980

Lituola strogguloides Arnaud Vanneau, 1980, pp. 362-366; pl. 51, figs. 1a-b, 5a-b; pl. 78, figs. $1-4$

Description. Test nautiloid, planispiral, involute. Protoconch globular, followed by two or three whorls of globular chambers. Wall agglutinated, microgranular, thick, with thick septa. Aperture multiple.

Remarks. Four specimens were observed in thin section, but generally specimens are badly preserved. 
Table 2. Stratigraphic distribution of Cretaceous benthic foraminfers and algae, Hole 879A (Takuyo-Daisan Guyot).

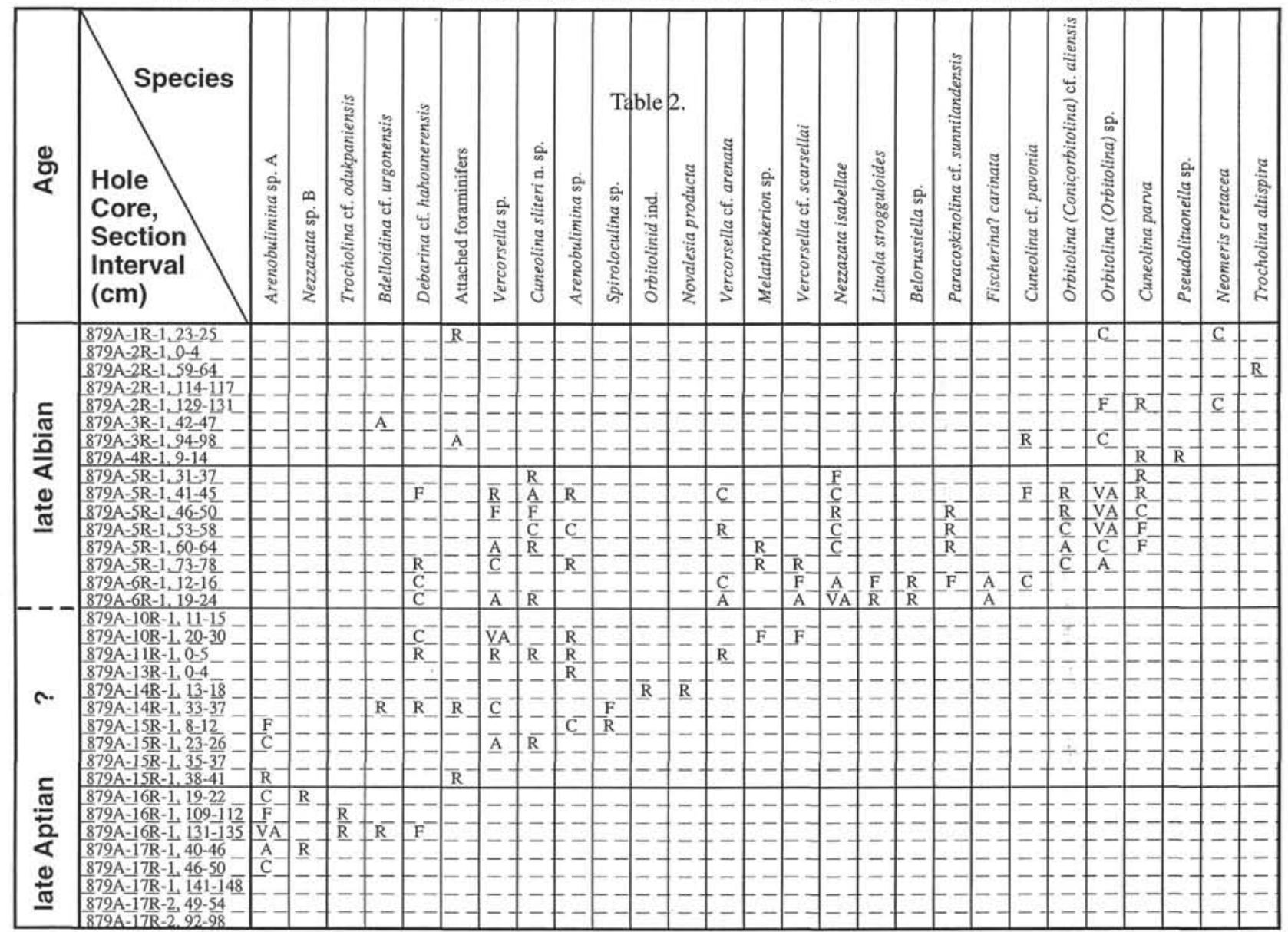

Note: Abundance abbreviations given in text.

Age and occurrence. late Aptian to Albian; MIT guyot from Samples 144-878A-52R-2, 108-111 cm, -53R-4, 127-130 cm, and -54R-2, 0-4 cm; Takuyo-Daisan Guyot from Samples 144-879A-6R-1, 12-16 cm, and -6R-1, $19-24 \mathrm{~cm}$

Known range. early Aptian

Geographic distribution. This species is known from the lower Aptian of the French Alps.

\section{Family COSCINOPHRAGMATIDAE Thalmann, 1951 Genus Bdelloidina Carter, 1877 \\ Bdelloidina sp. cf. B. urgonensis Wernli and Schulte, 1993} (Pl. 1, Figs. 4, 5)

Description. Test attached to the substrate, chambers low, broad, in uniserial arrangement, irregularly spreading over the attachment. Wall coarsely agglutinated with alveoles. Aperture indistinct in figured thin section, but either single or multiple consisting of a row of basal pores at base of apertural face.

Remarks. About 10 specimens were observed in thin sections. The Pacific specimens, although similar in morphology to the type species, are clearly alveolar, in contrast to Bdelloidina urgonensis, which is described as "discretely" alveolar.

Age and occurrence. Aptian to Albian; MIT Guyot from Samples 144878A-28M-1, 3-5 cm, -46M-2, 37-39 cm, -52R-2, 108-111 cm, and -74R-1, 6-10 cm; Takuyo-Daisan Guyot from Samples 144-879A-3R-1, 42-47 cm, $-14 \mathrm{R}-1,33-37 \mathrm{~cm}$, and $-16 \mathrm{R}-1,131-135 \mathrm{~cm}$.

Known range. Barremian

Geographic distribution. This species was originally described from the Barremian of the French Alps.

Subfamily NOVALESIINAE Loeblich and Tappan, 1984 Genus Novalesia Magniez, 1972a Novalesia producta (Magniez), 1972b
Spiroplectamminoides productus Magniez, 1972a, pp. 181, 185-186, and 189, pl. 1, figs. 1a-13b; pl. 4, figs. 1b, 2, 3, 4b, 5, 6b, 7b, 8-12

Description. Test small, elongate (maximum height, $0.30 \mathrm{~mm}$ ), triangular in axial section, early stage planispiral with a protoconch partly surrounded by four chambers, later biserial with a maximum of eight rows of chambers. Chambers subdivided by two to four thin radial beams. Wall agglutinated. Aperture a low interiomarginal slit.

Remarks. Five specimens were observed in axial and subaxial sections. The Pacific specimens, although similar in morphology to the type species, are smaller.

Age and occurrence. Aptian to Albian; MIT Guyot from Samples 144878A-22M-1, 0-4 cm, -71R-1, 83-87 cm, and -74R-1, 6-10 cm; TakuyoDaisan Guyot from Sample 144-879A-14R-1, 13-18 cm

Known range. Hauterivian to Cenomanian

Geographic distribution. This species was originally described from the Albian of the Pyrenees and is widespread along the margins of the Tethys.

Family ATAXOPHRAGMIIDAE Schwager, 1877 Subfamily ATAXOPHRAGMIINAE Schwager, 1877 Genus Arenobulimina Cushman, 1927 Arenobulimina sp. A (Pl. 1, Figs. 7-10)

Description. Test minute, conical, trochospiral (maximum height, 0.18 $\mathrm{mm}$; maximum diameter, $0.12 \mathrm{~mm}$ ) with a small umbilicus (PI. 1, Figs. 9-10). Chambers increase progressively in size with six to seven in the final whorl, separated by slightly depressed sutures. Wall agglutinated, thin, microgranular calcareous. Aperture at base of apertural face.

Remarks. About 20 specimens were observed in thin section that are smaller than previously described species of Arenobulimina.

Age and occurrence. late Aptian; MIT Guyot from Samples 144-878A49R-1, 127-130 cm; Takuyo-Daisan Guyot from Samples 144-879A-15R-1, 8-12 cm, -15R-1, 23-26 cm, -15R-1, 38-41 cm, -16R-1, 19-22 cm, -16R-1, 
Table 3. Ecological distribution of Cretaceous foraminifers, organisms, and algae, Hole 879A (Takuyo-Daisan Guyot).

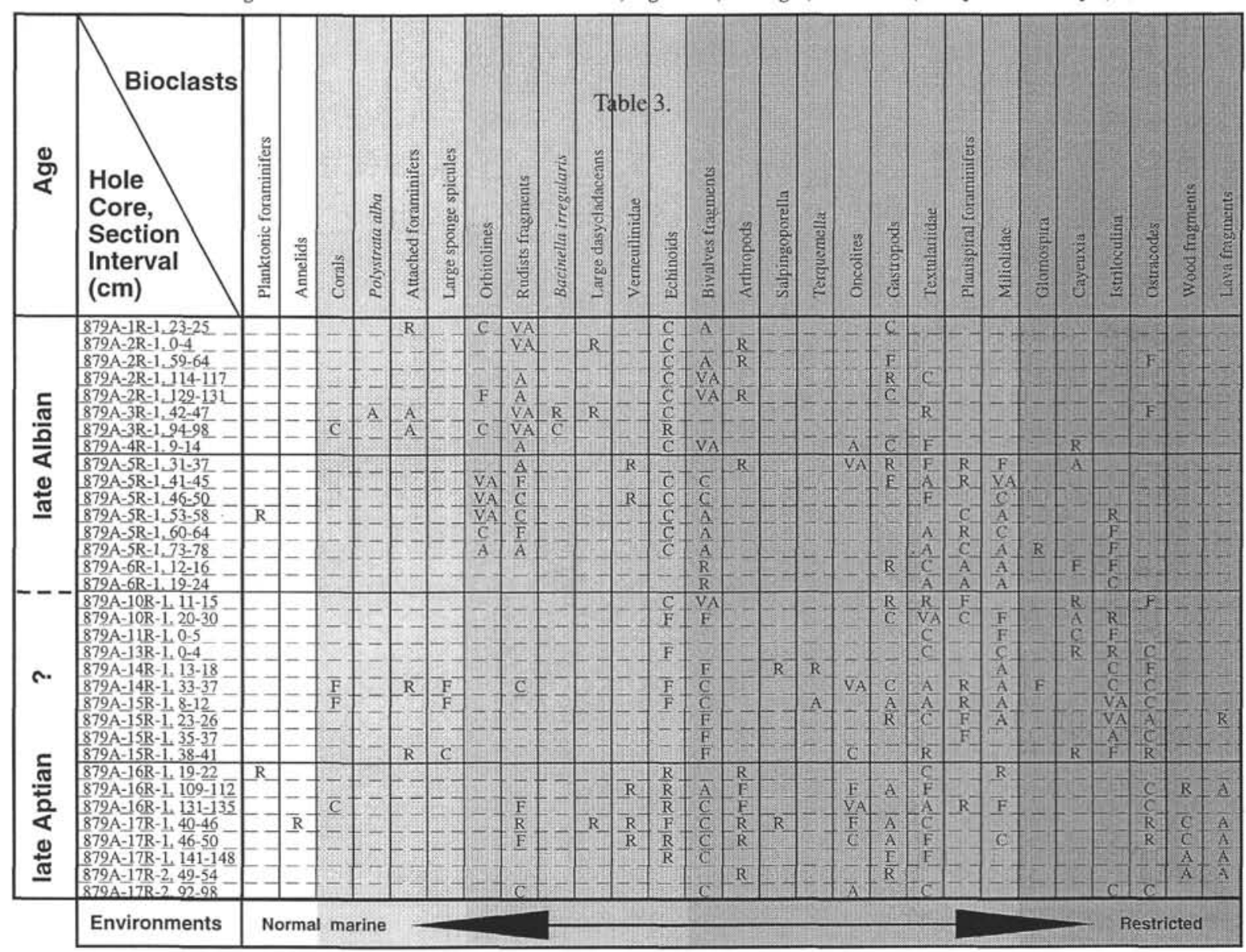

Note: Abundance abbreviations given in text.

109-112 cm, -16R-1, 131-135 cm, -17R-1, 22-26 cm, -17R-1, 40-46 cm, $-17 \mathrm{R}-1,46-50 \mathrm{~cm}$, and $-18 \mathrm{R}-1,22-26 \mathrm{~cm}$

\section{Arenobulimina sp. cf. A. chapmani Cushman, 1936

$$
\text { (PI. 1, Figs. 11,12) }
$$

Agglutinierende Foraminifere Grötsch, 1991, pl. 14, figs. 10-12 Textulariid foraminifera Grötsch and Flügel, 1992, pl. 33, figs. 5, 6

Description. Test conical, trochospiral, broad (maximum height, $0.22 \mathrm{~mm}$; maximum diameter, $0.30 \mathrm{~mm}$ ) with a wide umbilicus. Chambers inflated, increasing rapidly in size and number with up to five in the early stage and seven in the later stage, separated by depressed sutures. Wall agglutinated, thick, microgranular calcareous. Aperture at base of apertural face, obscured.

Remarks. Five specimens were observed in thin section. The Pacific specimens differ from typical Arenobulimina chapmani in being smaller and having an agglutinated calcareous test. Arenobulimina chapmani previously was identified from whole specimens and, thus, it is difficult to compare the morphology to specimens in thin section. Nevertheless, the present specimens tentatively are attributed to Arenobulimina chapmani as the overall morphology, number of chambers in the final whorl, and umbilical characteristics are similar.

Age and occurrence. late Albian; MIT Guyot from Samples 144-878A-

$5 \mathrm{R}-1,4-8 \mathrm{~cm},-10 \mathrm{R}-1,19-24 \mathrm{~cm},-12 \mathrm{R}-1,28-31 \mathrm{~cm}$, and $-22 \mathrm{M}-1,0-4 \mathrm{~cm}$

Known range. Albian

Geographic distribution. This species was described in Great Britain.

\section{Arenobulimina cochleata Arnaud Vanneau, 1980}

Arenobulimina cochleata Arnaud Vanneau, 1980, pp. 446-450, pl. 53, figs. 4-10; pl. 81, figs. 9-21; text-figs. 166,167

Description. Test small, conical, trochospiral (maximum height, $0.55 \mathrm{~mm}$; maximum diameter, $0.40 \mathrm{~mm}$ ). Chambers inflated, progressively enlarging in size, four to five in the final whorl, and separated by depressed sutures. Umbilicus medium in size. Wall agglutinated, thick, microgranular calcareous. Aperture at base of apertural face but obscured.
Remarks. Three specimens observed in thin section are identical in overall morphology to the figured types.

Age and occurrence. late Aptian; MIT Guyot from Sample 144-878A59R-3, 97-99 cm; Takuyo-Daisan Guyot from Samples 144-879A-13R-1, 0-4 $\mathrm{cm}$, and $-14 \mathrm{R}-1,0-5 \mathrm{~cm}$

Known range. Hauterivian to Aptian

Geographic distribution. This species, described from the lower Aptian of Vercors, France, is known from the margins of the Tethys in Switzerland, France, and Spain on the north, and from the Middle East and Italy on the south.

Genus Praechrysalidina Luperto Sinni, 1979

Praechrysalidina sp. cf. P. infracretacea Luperto Sinni, 1979 (Pl, 1, Figs. 13, 14)

Description. Test high trochospiral, conical, triserial throughout with chambers that increase rapidly in size. Sutures depressed. Wall agglutinated, thick, microgranular calcareous. Aperture a slit at base of a cribrate apertural plate.

Remarks. Five specimens were observed in thin section. Fine striae perpendicular to the test surface that typify the species were not identified in the Pacific specimens.

Age and occurrence. Aptian; MIT Guyot from Samples 144-878A-48R-1, $36-38 \mathrm{~cm}$, and $-57 \mathrm{R}-3,134-137 \mathrm{~cm}$

Known range. Valanginian? to Albian. According to Banner et al. (1991), the range should be limited to Aptian-Albian.

Geographic distribution. Originally described in Italy, this species is known from the Middle East to North Africa along the southern margin of the Tethys and in Mexico (Michaud and Fourcade, 1987).

\section{Subfamily GLOBOTEXTULARIIDAE Cushman, 1927 Genus Voloshinoides Barnard and Banner, 1980 Voloshinoides? sp. C (Pl. 1, Figs. 15-18)}

Description. Test conical, elongate, enrolled in high trochospire (maximum height, $0.37 \mathrm{~mm}$; maximum diameter, $0.12 \mathrm{~mm}$ ). Chambers four or five 
Table 4. Ecological distribution of Cretaceous foraminifers, organisms, and algae, Hole 878A (MIT Guyot).

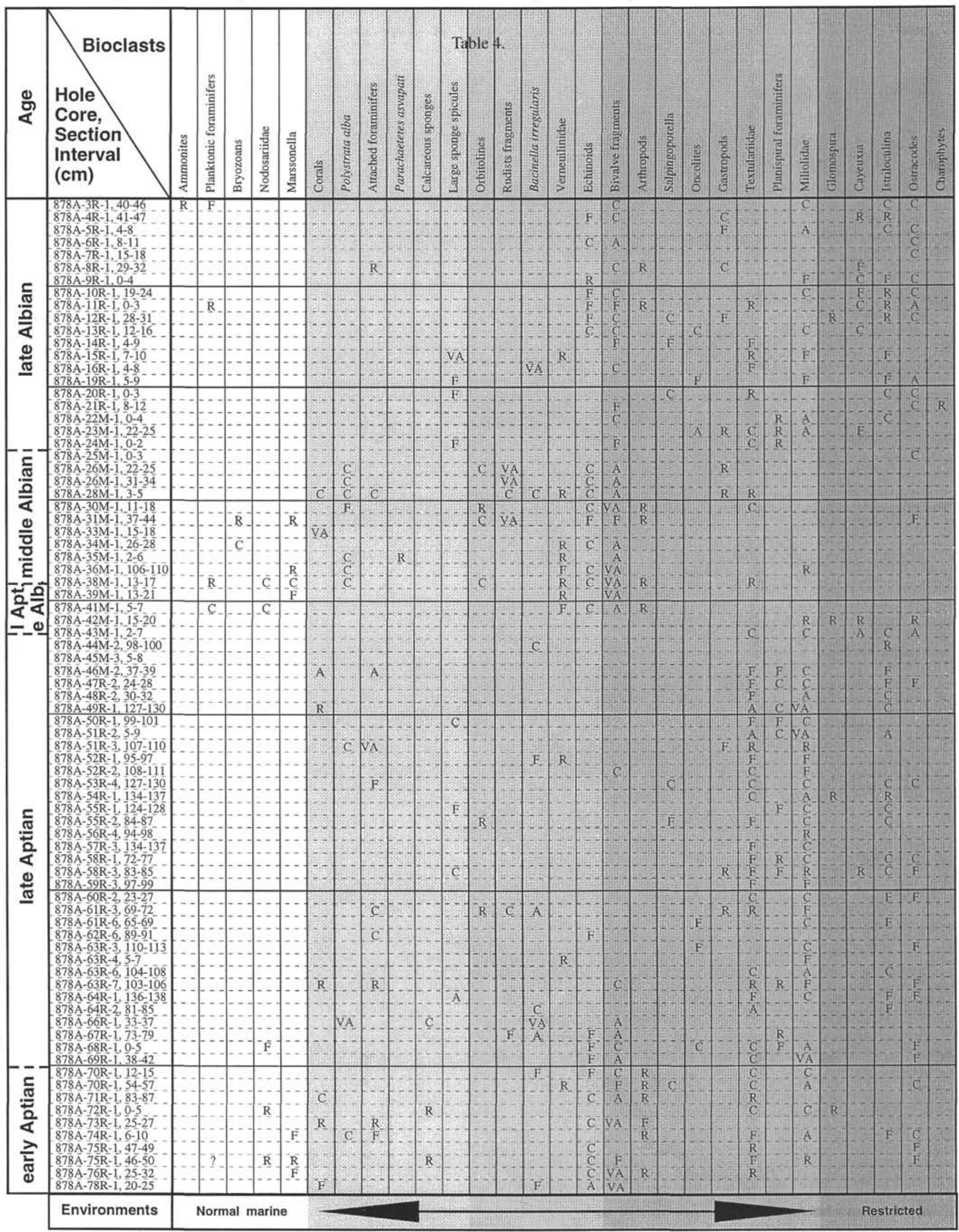

Note: Abundance abbreviations given in text. 
per whorl in the early stage and fewer in the later stage, subdivided by radial beams. Wall agglutinated, microgranular. Aperture obscured.

Remarks. Five specimens were observed in thin section. The presence of rafters is not perfectly clear in the Pacific specimens; thus, assignment to this genus is uncertain. If rafters are truly lacking, then these specimens belong to the genus Hagenowina.

Age and occurrence. late Aptian to middle Albian; MIT Guyot from Samples 144-878A-35M-1, 2-6 cm, and $-41 \mathrm{M}-1,4-8 \mathrm{~cm}$.

\section{Voloshinoides? sp. D}

(Pl. 1, Figs. 19, 20)

Praekurnubia sp. N'Da, 1984, pl. 9, figs. 16-19

Description. Test conical, triangular in axial section, trochospirally enrolled (maximum height, $0.34 \mathrm{~mm}$; maximum diameter, $0.30 \mathrm{~mm}$ ). Chambers decrease in number from three to two per whorl, subdivided by few radial beams.

Remarks. The six specimens observed in thin section differ from species $\mathrm{C}$ in their larger diameter, fewer initial chambers per whorl, and fewer beams subdividing the chambers. Similar specimens occur in upper Aptian (Gargasian) from France (N'Da, 1984).

Age and occurrence. Probably late Aptian; MIT Guyot from Samples 143-878A-42M-1, 26-32 cm, -45M-3, 5-8 cm, -50R-1, 75-79 cm, -68R-1, $0-5 \mathrm{~cm},-69 \mathrm{R}-1,38-42 \mathrm{~cm},-70 \mathrm{R}-1,12-15 \mathrm{~cm}$, and $-70 \mathrm{R}-1,54-57 \mathrm{~cm}$

Family NEZZAZATIDAE Hamaoui and Saint-Marc, 1970

Subfamily NEZZAZATINAE Hamaoui and Saint-Marc, 1970 Genus Nezzazata Omara, 1956

Nezzazata isabellae Arnaud Vanneau and Sliter (1995)

(Pl. 2, Figs. 1-3)

Nezzazata isabellae Arnaud Vanneau and Sliter (1995), fig. 7; pl. 2, figs. 11-24

Description. Test a low trochospiral, biconvex, spiral side more convex than umbilical side, periphery rounded, umbilicus closed (maximum height, $0.14 \mathrm{~mm}$; maximum diameter, $0.20 \mathrm{~mm}$ ). Protoconch rounded, at the apex of the dorsal face, followed by 2 to 3 whorls of up to 12 chambers per whorl, separated by slightly depressed sutures. Wall of microgranular calcite, imperforate. Aperture extends from the umbilicus to the periphery, then bends parallel to the peripheral margin, with an apertural tooth and toothplate that extends back in the direction of the previous aperture.

Remarks. About 50 specimens were observed in thin section.

Age and occurrence. middle to late Albian; MIT Guyot from Sections 144-878A-3R-1 to -28M-1; Takuyo-Daisan Guyot from Sections 144 $879 \mathrm{~A}-5 \mathrm{R}-1$ to $-6 \mathrm{R}-1$

Known range. late Aptian to early Albian

Geographic distribution. This species was described from the upper Aptian to the Albian of the Resolution (Site 866) and Allison (Site 865) guyots, drilled during Leg 143.

\section{Nezzazata sp. B2}

(Pl. 2, Figs. 8, 9)

Description. Test small, a low trochospiral, spiral side more convex than umbilical side, periphery rounded, umbilicus closed (maximum height, 0.10 $\mathrm{mm}$; maximum diameter, $0.15 \mathrm{~mm}$ ). Protoconch rounded, followed by three whorls of chambers with maximum ten chambers visible per whorl that increase very gradually in size, separated by slightly depressed sutures.

Remarks. About five specimens were observed in thin section. Nezzazata sp. B is one of the smaller forms of Nezzazata. The same species was observed at the bottom of the Allison Guyot Cretaceous succession (Site 865).

Age and occurrence. late Aptian; Takuyo-Daisan Guyot from Sample 144-879A-17R-1, 0-5 cm

\section{Nezzazata?sp. C}

(Pl. 2, Figs. 4-7)

Description. Test a low trochospiral, spiral side more convex than umbilical side, periphery rounded, umbilicus closed (maximum height, $0.20 \mathrm{~mm}$ maximum diameter, $0.35 \mathrm{~mm}$ ). Protoconch rounded, followed by three whorls of chambers with eight chambers visible per whorl, which increase rapidly in size, separated by slightly depressed sutures (PI. 2, Fig. 5). Apertural toothplate indistinct.

Remarks. About 40 specimens were observed in thin section. These specimens are larger and have chambers that increase more rapidly in size than younger nezzazatids. Similar specimens from the Barremian to Aptian of France and Spain have been referred to Valvulineria n. sp. 2 (Arnaud Vanneau, 1980)

Age and occurrence. Aptian; MIT Guyot from Samples 144-878A-42M$1,26-32 \mathrm{~cm},-45 \mathrm{M}-3,123-125 \mathrm{~cm},-48 \mathrm{R}-2,30-32 \mathrm{~cm},-49 \mathrm{R}-1,127-130 \mathrm{~cm}$,
$-51 \mathrm{R}-2,5-9 \mathrm{~cm},-52 \mathrm{R}-2,108-111 \mathrm{~cm},-55 \mathrm{R}-3,46-49 \mathrm{~cm},-61 \mathrm{R}-3,69-72 \mathrm{~cm}$, $-62 \mathrm{R}-7,103-105 \mathrm{~cm},-63 \mathrm{R}-7,103-106 \mathrm{~cm},-73 \mathrm{R}-1,25-27 \mathrm{~cm}$, and $-74 \mathrm{R}-1$, $6-10 \mathrm{~cm}$

Valvulineria Cushman, 1926

Remarks. We tentatively place the following specimens in the genus Valvulineria based on the shape of the test, although they differ in having a microgranular, imperforate wall and an aperture consisting of a slit at the base of the apertural face.

$$
\text { Valvulineria? n. sp. 1, Arnaud Vanneau, } 1980
$$$$
\text { (Pl. 2, Figs. 10-12) }
$$

Description. Test small, trochospiral, biconvex, spiral side more convex than the umbilical side, umbilicus closed (maximum height, $0.11 \mathrm{~mm}$; maximum diameter, $0.15 \mathrm{~mm}$ ). Protoconch rounded, at the apex of the trochospire, followed by three whorls of chambers with up to eight chambers per whorl, which increase gradually in size. Apertural toothplate indistinct.

Remarks. About 20 specimens were observed in thin section that closely resemble species of Nezzazata in their test shape and size, chamber arrangement, and wall structure. The lack of a visible toothplate, however, prevents assignment to this genus and is the reason why we tentatively assign these numerous specimens to the genus Valvulineria.

Age and occurrence. Aptian; MIT Guyot from Samples 143-878A-49R-1, $127-130 \mathrm{~cm},-53 \mathrm{R}-4,127-130 \mathrm{~cm},-62 \mathrm{R}-2,23-27 \mathrm{~cm},-61 \mathrm{R}-6,65-69 \mathrm{~cm}$, $-63 \mathrm{R}-7,103-107 \mathrm{~cm},-64 \mathrm{R}-2,81-85 \mathrm{~cm},-68 \mathrm{R}-1,0-5 \mathrm{~cm},-69 \mathrm{R}-1,38-42 \mathrm{~cm}$, $-70 \mathrm{R}-1,54-57 \mathrm{~cm},-74 \mathrm{R}-1,6-10 \mathrm{~cm}$, and $-75 \mathrm{R}-1,141-143 \mathrm{~cm}$

Known range. Valanginian to early Aptian

Geographic distribution. This widespread species was first identified in the Barremian of Vercors, France.

\section{Family CUNEOLINIDAE Saidova, 1981}

= Subfamily SABAUDIINAE Brönnimann, Decrouez and Zaninetti, 1983 Genus Sabaudia Charollais and Brönnimann, 1965 Sabaudia minuta (Hofker Jr.), 1965

(Pl. 2, Figs. 13, 14)

Textulariella minuta Hofker Jr., 1965, pp. 186-187, pl. 3, figs. 5-6; pl. 4, figs. $1-9$

Sabaudia minuta (Hofker), Charollais and Brönnimann, 1965, pp. 620-621, pl. 1, figs. 1-6; text-fig. 4

Sabaudia minuta (Hofker), Amaud Vanneau and Chiocchini, 1985, p. 29-32, pl. 10, figs. $1-14$; text-fig. 4

Description. Test a small high cone with flattened base (maximum height, $0.20 \mathrm{~mm}$; maximum diameter, $0.20 \mathrm{~mm}$ ). Apical angle varies from $17^{\circ}$ to $20^{\circ}$ in axial section parallel to the plane of biseriality. Initial trochospiral stage formed by a rounded protoconch and two to three small chambers with a microgranular wall covered by a thick yellow calcitic layer, followed by later biserial stage with up to five chambers, each subdivided by radial beams. Horizontal rafters are not present. Wall of biserial stage agglutinated, microgranular. Aperture an interiomarginal slit.

Remarks. Three specimens were observed in thin section.

Age and occurrence. middle to late? Albian; MIT Guyot from Samples 144-878 A-33M-1, 22-25 cm, and -22M-1, 3-4 cm

Known range. Valanginian to Cenomanian

Geographic distribution. The species is widespread along the margins of the Tethys,

Subfamily CUNEOLININAE Saidova, 1981

Genus Vercorsella Arnaud Vanneau, 1980

Vercorsella sp. cf. V. arenata Arnaud Vanneau, 1980

(PI. 2, Figs. 15-18)

Description. Test small, conical (maximum height, $0.60 \mathrm{~mm}$; maximum diameter, $0.30 \mathrm{~mm}$ ) with an apical angle that varies from $25^{\circ}$ to $30^{\circ}$ in axial section parallel to the plane of biseriality. Initial trochospiral stage consists of a rounded protoconch, a rounded deuteroconch, and one or two chambers (PI. 2. Figs. 16-18), followed by a biserial stage with up to six chambers that are slightly compressed parallel to the plane of biseriality and subdivided by four to five radial beams that extend from the outer wall toward the plane of biseriality. Horizontal rafters are not present. Wall of biserial stage microgranular. Aperture a row of three or four rectangular pores.

Remarks. About 50 specimens were observed in thin sections. The Pacific specimens differ from typical Vercorsella arenata in being less compressed and in having fewer vertical partitions in chambers of the biserial stage. The test is microgranular only and not arenaceous. 
Age and occurrence. Aptian to Albian; common in MIT Guyot from Sections 144-878A-1R-1 to -75R-1; common in Takuyo-Daisan Guyot from Sections 144-879A-5R-1 to -11R-1

Known range. Barremian to Albian

Geographic distribution. Although known from both margins of the Tethys, the species occurs predominantly along the northern margin in Romania, Switzerland, France, and Spain.

\section{Vercorsella sp. cf. V. immaturata $\mathrm{He}, 1982$}

(Pl. 2, Figs. 22-27)

Description. Test small, conical (maximum height, $0.35 \mathrm{~mm}$; maximum diameter, $0.20 \mathrm{~mm}$ ), apical angle varies from $18^{\circ}$ to $30^{\circ}$ in axial section parallel to the plane of biseriality. Embryonic apparatus formed by a rounded protoconch and a small deuteroconch (PI. 2, Figs. 26-27) followed by one chamber. Biserial stage with up to six rows of chambers that are slightly compressed parallel to the plane of biseriality and subdivided by two or three short radial beams that extend less than halfway to the plane of biseriality and are thinner toward the center. Horizontal rafters are not present. Wall microgranular.

Remarks. About 20 specimens were observed in thin section. The Pacific specimens differ from typical Vercorsella immaturata in having a more acute apical angle, and fewer and shorter radial beams in the chambers of the biserial stage.

Age and occurrence. Aptian; MIT Guyot from Samples 143-878A-46M$2,37-39 \mathrm{~cm},-47 \mathrm{R}-2,24-28 \mathrm{~cm},-49 \mathrm{R}-1,127-130 \mathrm{~cm},-51 \mathrm{R}-2,5-9 \mathrm{~cm},-53 \mathrm{R}-4$, $78-80 \mathrm{~cm},-54 \mathrm{R}-1,134-137 \mathrm{~cm},-55 \mathrm{R}-1,124-128 \mathrm{~cm},-68 \mathrm{R}-1,0-5 \mathrm{~cm}$, $-70 \mathrm{R}-1,12-15 \mathrm{~cm}$, and $-74 \mathrm{R}-1,6-10 \mathrm{~cm}$

Known range. Aptian to Albian

Geographic distribution. Previously, the species was restricted to Xizang, Tibet.

\section{Vercorsella sp. cf. V. scarsellai De Castro, 1963}

$$
\text { (PI. 2, Figs. 19-21) }
$$

Description. Test small, elongate, conical (maximum height, $1.05 \mathrm{~mm}$; maximum diameter, $0.35 \mathrm{~mm}$ ), apical angle varies from $15^{\circ}$ to $28^{\circ}$ in axial section parallel to the plane of biseriality. Initial trochospiral stage not observed on these specimens, followed by a biserial stage with up to eight chambers, slightly compressed parallel to the plane of biserality and subdivided by a maximum of five radial beams. Horizontal rafters are lacking. Wall microgranular. Aperture a row of rectangular pores at base of septal face.

Remarks. About 20 specimens were observed in thin section. The Pacific specimens differ from typical Vercorsella scarsellai in being smaller and having fewer chambers and fewer but thicker radial beams.

Age and occurrence. Aptian to Albian; MIT Guyot from Sections 144 $878 \mathrm{~A}-4 \mathrm{R}-1$ to $-70 \mathrm{R}-1$

Known range. Barremian to Albian

Geographic distribution. This species is known from the southern margin of the Tethys in Italy, Croatia, Slovenia, North Africa, and the Middle East.

\section{Vercorsella sp. A}

(Pl. 4, Figs. 1-5)

Description. Test elongate, high conical (maximum height, $0.8 \mathrm{~mm}$; maximum diameter, $0.45 \mathrm{~mm}$ ), apical angle varies from $22^{\circ}$ to $27^{\circ}$ in axial section perpendicular to the plane of biseriality. Initial trochospiral stage consists of a rounded protoconch, capped by a rounded deuteroconch and one chamber largely opened in direction of the embryonic apparatus (PI. 4, Figs. $1-5$ ), followed by biserial stage with up to nine chambers, slightly compressed parallel to the plane of biseriality and subdivided by a several radial beams. Horizontal rafters probably exist in ultimate chambers. Wall agglutinated, microgranular. Aperture a row of rectangular pores at base of septal face.

Remarks. About 30 specimens were observed in thin section. The Pacific specimens somewhat resemble Vercorsella scarsellai, but they differ in being of larger size and in having a well-developed embryonic apparatus and numerous radial beams.

Age and occurrence. Aptian to Albian; MIT Guyot from Sections 144 878A-3R-1 to -69R-1; Takuyo-Daisan Guyot from Sections 144-879A-5R-1 to $-11 R-1$

\section{Genus Cuneolina d'Orbigny, 1839}

Cuneolina sp. cf. C. pavonia d'Orbigny, 1846

$$
\text { (PI. 3, Figs. 10-12) }
$$

Cuneolina pavonia d’Orbigny, Grötsch, 1991, pl. 19, fig. 5 Cuneolina pavonia d'Orbigny, Grötsch et al., 1993, fig. 5B-E
Description. Test compressed, flabelliform (maximum height, $1.8 \mathrm{~mm}$; maximum diameter, $4 \mathrm{~mm}$ ), with a very large and complex embryonic apparatus with a large protoconch capped by a large deuteroconch subdivided by numerous beams and rafters (PI. 3, Fig. 10), followed by a larger biserial stage. Chambers broad, subdivided by numerous radial beams that thin toward the plane of biseriality and two to three transverse rafters; interior subdivided into a network of rectangular chamberlets close to the outer wall. Wall keriothecal microgranular, with very small, tubular alveoles.

Remarks. About 20 specimens were observed in thin sections. The Pacific specimens are smaller and have a thinner, less agglutinated wall than typical Cuneolina pavonia and may represent another species. However, without whole specimens and more definitive thin sections, we cannot distinguish these specimens from Cuneolina pavonia.

Age and occurrence. late Albian; MIT Guyot from Sample 144-878A-5R1, 28-31 cm, Sample 144-878B-1R-1, 36-39 cm, and Sample 144-878C-1R-1, 28-31 cm; Takuyo-Daisan Guyot from Samples 144-879A-3R-1, 94-98 cm, $-5 \mathrm{R}-1,41-45 \mathrm{~cm}$, and $-6 \mathrm{R}-1,12-16 \mathrm{~cm}$

Known range. late Albian to Santonian

Geographic distribution. The species is known along the southern margin of the Tethys in the Middle East, Egypt, Greece, Italy, Albania, Yugoslavia, and North Africa, and from the northern margin in France and Spain.

\section{Cuneolina parva Henson, 1948}

Cuneolina pavonia var. parva Henson, 1948, pp. 624-627, pl. XIV, figs. 1-6; pl. XVII, figs. 7-12; pl. XVIII, figs. 12-14

?Cuneolina laurentii Sartoni and Crescenti, Shiba, 1988, pl. 7, figs. 25-28

Cuneolina pavonia d'Orbigny, Grötsch, 1991, pl. 19, figs. 3, 4?, 6-8

Description. Test compressed, conical to flabelliform (maximum height, $1.3 \mathrm{~mm}$; maximum diameter, $0.9 \mathrm{~mm}$ ). Embryonic apparatus composed of a large, oval, protoconch covered by a deuteroconch subdivided by beams and rafters, followed by a broad, low, biserial stage with up to 12 chambers. Chambers compressed parallel to the plane of biseriality and subdivided by radial beams and 1 or 2 transverse rafters that produce a rectangular network of chamberlets. Wall keriothecal microgranular, composed of small, tubular alveoles. Aperture a row of rectangular pores at base of septal face.

Remarks. The Pacific taxon, consisting of about 25 specimens examined whole and in thin section, are very similar to the types of Cuneolina parva described from the Santonian of Egypt. The published age of the type locality, however, is incorrect and instead is probably Albian (A.I. Kenawi, pers. comm., 1992).

Age and occurrence. late Albian; MIT Guyot from Sections 144-878A3R-1 (cuttings), $-4 \mathrm{R}-1,41-47 \mathrm{~cm},-5 \mathrm{R}-1,4-8 \mathrm{~cm},-8 \mathrm{R}-1,29-32 \mathrm{~cm},-9 \mathrm{R}-1$, $0-4 \mathrm{~cm},-14 \mathrm{R}-1,14-18 \mathrm{~cm},-22 \mathrm{M}-1,0-4 \mathrm{~cm}$, and $-23 \mathrm{M}-1,22-25 \mathrm{~cm}$; TakuyoDaisan Guyot from Samples 144-879A-2R-1, 129-131 cm, -3R-1, 94-98 cm, $-4 R-1,9-14 \mathrm{~cm},-5 \mathrm{R}-1,31-37 \mathrm{~cm},-5 \mathrm{R}-1,41-45 \mathrm{~cm},-5 \mathrm{R}-1,46-50 \mathrm{~cm},-5 \mathrm{R}-1$, $53-58 \mathrm{~cm},-5 \mathrm{R}-1,60-64 \mathrm{~cm}$, and $5 \mathrm{R}-1,73-78 \mathrm{~cm}$

Known range. Albian to Cenomanian, Santonian?

Geographic distribution. The species is mostly known from the southern margin of the Tethys in the Middle East, Egypt, Greece, Italy, Albania, Yugoslavia, and North Africa, and from the northern margin in France and Spain.

\section{Cuneolina sliteri $\mathrm{n} . \mathrm{sp}$.}

(Fig. 1; Pl. 3, Figs. 1-9)

Cuneolina sp. Arnaud Vanneau and Sliter (1995), pl. 4, figs. 10-11

Description. Test small, triangular, compressed, conical (maximum height, $1.15 \mathrm{~mm}$; maximum diameter, $0.78 \mathrm{~mm}$ ). Embryonic apparatus formed by a small, round or oval protoconch, and a deuteroconch subdivided by a few rafters and beams, followed by a short biserial stage with up to six or seven chambers compressed parallel to the plane of biseriality. Chambers subdivided by radial beams that thin toward the center; horizontal rafters lacking in first chambers. Wall keriothecal, microgranular, with very small, tubular alveoles. Aperture a row of elongated pores at base of septal face.

Remarks. About 40 specimens were observed whole and as oriented and random thin sections. Comparisons with other species of Cuneolina. The genus Cuneolina was revised by Arnaud Vanneau and Sliter (1995). It is characterized by a keriothecal test and an embryonic apparatus made by a protoconch and a subdivided deuteroconch. Only Cuneolina pavonia and Cuneolina parva show these characteristic features and belong to this genus. Also, the Pacific species is the smallest Cuneolina described and probably the oldest. The conical test is triangular and never flabelliform, as are Cuneolina parva or Cuneolina pavonia. The deuteroconch displays only a few beams and rafters, and sometimes only one is visible in thin section. Chambers are subdivided by 
only radial beams in the initial chambers and by very few horizontal rafters in later chambers.

Holotype. Subaxial section in the plane of biseriality (PI. 3, Fig. 1)

Type locality. Takuyo-Daisan Guyot, Sample 144-879A-5R-1, 31-37 cm

Age and occurrence. late Aptian to Albian; very common in MIT Guyot from Samples 144-878A-3R-1, $40-46 \mathrm{~cm}$, to $-64 \mathrm{R}-2,81-85 \mathrm{~cm}$; TakuyoDaisan Guyot from Samples 144-879A-5R-1,31-37 cm, to - $15 R-1,23-26 \mathrm{~cm}$

Derivatio nominis. The species is dedicated to William V. Sliter of the U.S. Geological Survey.

Family ORBITOLINIDAE Martin, 1890

Subfamily DICTYOCONINAE Moullade, 1965

Genus Coskinolinella Delmas and Deloffre, 1961

Coskinolinella daguini Delmas and Deloffre, 1961

$$
\text { (Pl. 4, Fig. 6) }
$$

Coskinolinella daguini Delmas and Deloffre, 1961, pp. 167-170, pl. 1, figs. $1-8$; text-fig. 1

Coskinolinella daguini Delmas and Deloffre, Cherchi in Schroeder and Neumann, 1985 , pp. $52-54$, pl. 23 , figs. 1-16

Description. Test low conical, with concave base. Small early planispiral stage followed by an uniserial stage made by discoidal chambers subdivided by radial invaginations of the chamber floor. Partitions alternate regularly from one chamber to the next. There are no beams and rafters subdividing the marginal zone. Wall microgranular. Aperture of oblique pores between adjacent chambers.

Age and occurrence. late Aptian; MIT Guyot from Sample 144-878A$41 \mathrm{M}-1,4-8 \mathrm{~cm}$

Known range. late Aptian to early Albian

Geographic distribution. southwestern France and northern Spain

Coskinolinella navarrensis Ramirez del Pozo, 1971

(Pl. 4, Fig. 7)

Coskinolinella navarrensis Ramirez del Pozo, 1971, pp. 252-253, pl. 64, fig. 2

Coskinolinella navarrensis Ramirez del Pozo, Cherchi in Schroeder and Neumann, 1985, pp. 55-56, pl. 25, figs. 1-7

Description. Test discoidal to very low conical, with concave base. Small early planispiral stage followed by an uniserial stage made by discoidal chambers subdivided by radial invaginations of the chamber floor. Partitions alternate regularly from one chamber to the next. There are radial beams and one to two rafters subdividing the marginal zone. Wall microgranular. Aperture of oblique pores between adjacent chambers.

Age and occurrence. Probably middle Albian, MIT Guyot from Samples 144-878A-26M-1, 31-35 cm, and -31M-1, 22-26 cm

Known range. late middle Albian to early late Albian

Geographic distribution. southeastern France and northern Spain

Genus Paracoskinolina Moullade, 1965

Paracoskinolina sp. cf. P. sunnilandensis (Maync), 1955

$$
\text { (Pl. 5, Figs. 5, 6) }
$$

Description. Test small, high conical (apical angle from $35^{\circ}$ to $40^{\circ}$ ), with a flat base (maximum height, $0.7 \mathrm{~mm}$; maximum diameter, $0.6 \mathrm{~mm}$ ). Embryonic apparatus indistinct. Chamber margin subdivided by radial beams that thicken slightly toward the center of test, transverse rafters lacking. Central zone subdivided by pillars that appear continuous from one chamber to the next.

Remarks. The Pacific specimens, represented by ten thin sections, differ from typical representatives of Paracoskinolina sunnilandensis in their small size and reduced central zone. The general arrangement of the beams and pillars, is however similar to the type specimens.

Age and occurrence. late Albian; Takuyo-Daisan Guyot from Samples 144-879A-3R-1, 67-69 cm, -5R-1, 46-50 cm, -5R-1, 53-55 cm, -5R-1, 60-64 $\mathrm{cm},-6 \mathrm{R}-1,12-16 \mathrm{~cm}$, and $-6 \mathrm{R}-1,19-24 \mathrm{~cm}$

Known range. Hauterivian to Albian

Geographic distribution. Originally described from the Albian of Florida, this species is known from the northern margin of the Tethys in France and Switzerland, and from Texas, Mexico, Guatemala, and Venezuela.

Subfamily ORBITOLININAE Martin, 1890

Genus Orbitolina d'Orbigny, 1850

Subgenus Mesorbitolina Schroeder, 1962

Orbitolina (Mesorbitolina) sp. cf. O. (M.) pervia Douglass, 1960

(PI. 4, Fig. 10)
Description. Test large, low conical, base flat to slightly convex (maximum height, $1.1 \mathrm{~mm}$; maximum diameter, $2 \mathrm{~mm}$ ). Embryonic apparatus not visible. Marginal zone subdivided by two orders of radial beams and by one set of rafters. Radial zone subdivided by radial zigzag partitions that do not thicken and are not triangular in axial or subaxial sections; partitions alternate regularly from one chamber to the next. Test calcareous and agglutinated.

Remarks. Six specimens were observed in thin sections. The Pacific specimens are similar to the type specimens of Orbitolina (Mesorbitolina) pervia, but as the embryonic apparatus is missing on thin sections, we cannot positively identify the species. The Pacific specimens show the same characteristic uniform thickness of the central partitions as in Orbitolina (Mesorbitolina) pervia. The lack of thickening of the central partitions also occurs in members of the subgenus Conicorbitolina and the genus Neoiraqia from the upper Albian to the lower Cenomanian. However, the partitions in these taxa are more regular and thinner, and the very narrow marginal zone is obscured in relationship to the network made by the numerous beams and rafters.

Age and occurrence. late Aptian; MIT Guyot from Sample 144-878A$42 \mathrm{M}-1,26-32 \mathrm{~cm}$

Known range. late Aptian to middle Albian

Geographic distribution. Originally described from the Albian of Texas, this species is widespread along the margins of the Tethys and identified in Spain, southeastern France, Croatia, Algeria, and Venezuela (Görog and Arnaud Vanneau, in press).

\section{Orbitolina (Mesorbitolina) texana oculata Douglass, 1960}

(Pl. 4, Figs. 8, 9)

Orbitolina oculata Douglass, 1960, pp. 39-41, pl. 10, figs. 1-19

Description. Test large, conical, base convex (maximum height, $2.4 \mathrm{~mm}$; maximum diameter, $4.6 \mathrm{~mm}$ ). Embryonic apparatus composed of a rounded protoconch $(0.10 \mathrm{~mm})$ capped by a deuteroconch subdivided by beams and rafters (Pl. 4, Fig. 9) and equally developed subembryonic zone. Marginal zone subdivided by two orders of radial beams and by rafters. Radial zone subdivided by radial zigzag partitions that thicken rapidly and are triangular in axial or subaxial sections; partitions alternate regularly from one chamber to the next. Test calcareous and agglutinated with many calcite eyes (sponge spicules).

Remarks. About 20 specimens were observed in thin sections. The Pacific specimens are similar to type specimens of Orbitolina (Mesorbitolina) texana oculata illustrated by Douglass (1960).

Age and occurrence. middle Albian; MIT Guyot from Sample 144-878A$30 \mathrm{M}-1$ (cuttings), $-31 \mathrm{M}-1,22-26 \mathrm{~cm},-31 \mathrm{M}-1,32-35 \mathrm{~cm},-31 \mathrm{M}-1,37-44 \mathrm{~cm}$, and $-37 \mathrm{M}-1,32-35 \mathrm{~cm}$

Known range. Albian

Geographic distribution. Originally described from the Albian of Texas, this species is widespread along the margins of the Tethys.

Subgenus Conicorbitolina Schroeder, 1973

Orbitolina (Conicorbitolina) sp. cf. O. (C.) aliensis Zhang, 1982 (Pl. 5, Figs. 1, 2)

Description. Test large, low conical, base convex (maximum height, 2 $\mathrm{mm}$; maximum diameter, $3.4 \mathrm{~mm}$ ). Embryonic apparatus composed of a planoconvex protoconch $(0.40-0.45 \mathrm{~mm})$ capped by a deuteroconch subdivided by numerous beams and rafters producing polygonal network (PI. 5, Fig. 2 ) and subembryonic zone. Later chambers display radial zone divided by two orders of radial beams and by horizontal rafters that produce rectangular chamberlets. Radial zone subdivided by radial zigzag partitions that thicken gradually and become triangular in axial or subaxial sections; partitions alternate regularly from one chamber to the next. Test calcareous agglutinated.

Remarks. About 20 specimens were observed in thin sections. The Pacific specimens are similar to $O .(C$. $)$ aliensis described from Xizang. Tibet, that have the same type of embryonic apparatus. The poor quality of the embryonic apparatus in the thin sections from Takuyo-Daisan prevents a positive identification with the Tibetan material.

Age and occurrence. latest Albian; Takuyo-Daisan Guyot from Sections 144-879A-3R-1 to -6R-1

Known range. Albian

Geographic distribution. Previously, the species was restricted to Xizang, Tibet.

\section{Subgenus Orbitolina d'Orbigny, 1850 Orbitolina (Orbitolina) sp.}

$$
\text { (PI. 5, Figs. 3-4) }
$$

Description. Test large, flat to low conical, base flat to concave (maximum height, $1.70 \mathrm{~mm}$; maximum diameter, $5.80 \mathrm{~mm}$ ). Embryonic apparatus com- 
posed of an oval protoconch $(0.40 \mathrm{~mm})$, capped by a large deuteroconch divided by numerous beams and rafters producing a polygonal network ( $\mathrm{Pl} .5$, Fig. 4) and subembryonic zone. Later chambers display radial zone subdivided by 2 to 3 orders of radial beams and by horizontal rafters that produce rectangular chamberlets. Radial zone subdivided by radial zigzag partitions that thicken and become triangular in axial or subaxial sections; partitions alternate regularly from one chamber to the next. Test calcareous and agglutinated.

Remarks. About 30 specimens were observed in thin sections. The conical form and the calcareous test of Pacific specimens are not comparable to those of the other species of Orbitolina.

Age and occurrence. latest Albian; Takuyo-Daisan Guyot from Sections 144-879A-2R-1 to $-5 R-1$.

\section{Family INVOLUTINIDAE Bütschli, 1880 \\ Genus Trocholina Paalzow, 1922 \\ Trocholina altispira Henson, 1948}

(Pl. 5, Fig. 7)

Trocholina altispira Henson, 1948, pp. 455-456, pl. XI, fig. 3a-b; pl. XIII, fig. 8

Trocholina altispira Henson in Arnaud Vanneau and Boisseau, 1988, pp. $362-363$, fig. 5 ; pl. 1, figs. $6-10$; pl. 6, figs. 22-27

Description. Test acute conical, protoconch indistinct, sections of the following tubular second chamber are triangular in the figured subaxial section and strongly eroded, umbilical side convex. Wall calcareous, very thin, eroded in figured specimen.

Remarks. Two specimens were observed in thin section that are similar in morphology and size to specimens of Trocholina altispira from the Middle East.

Age and occurrence. late Albian; Takuyo-Daisan Guyot from Sample 144-879A-3R-1, 67-69 cm

Known range. late Albian to early Cenomanian

Geographic distribution. Previously, this species was restricted to the southern margin of the Tethys in the Middle East.

\section{Trocholina sp. cf. T. odukpaniensis Dessauvagie, 1968}

$$
\text { (Pl. 5, Fig. 8) }
$$

Description. Test small, low conical (maximum diameter, $0.65 \mathrm{~mm}$ ). Protoconch indistinct, tubular second chamber with four whorls visible; subaxial section of tubular chamber shows triangular section that bends slightly toward umbilical side, umbilical side flat to slightly convex.

Remarks. Two specimens were observed in thin section. They are similar in morphology to the type specimens of Trocholina odukpaniensis, but their size is smaller and the umbilical side is not enough well preserved to be sure that specimens correspond really to $T$. odukpaniensis.

Age and occurrence. late Aptian; Takuyo-Daisan Guyot from Samples 144-879A-16R-1, 109-112 cm, and -16R-1, 131-135 cm

Known range. Hauterivian to early Cenomanian

Geographic distribution. This species was described from the upper Albian to the lower Cenomanian sediments of Nigeria and is reported from the margins of the Tethys.

Genus Neotrocholina Reichel, 1956

$$
\text { Neotrocholina sp. cf. N. infragranulata Noth, } 1951
$$

Description. Test low conical with a thick yellow calcitic crust. Protoconch indistinct. Second chamber tubular, triangular in subaxial section with a small acute angle toward the center of the test trochospirally enrolled in four whorls. Umbilical side flat, with characteristic marginal ridge and numerous small pillars.

Remarks. Two specimens were observed in oblique thin section that closely resemble Neotrocholina infragranulata. The lack of additional thin sections, however, prevents us from confirming our identification of this species that was originally described from whole specimens.

Age and occurrence. early Aptian; MIT Guyot from Samples 144-878A$74 \mathrm{R}-1,6-10 \mathrm{~cm}$, and $-75 \mathrm{R}-1,0-4 \mathrm{~cm}$

Known range. Hauterivian to early Aptian

Geographic distribution. This widespread species was originally described from the Hauterivian of Austria.

Family HAUERINIDAE Schwager, 1876 Subfamily SIPHONAPERTINAE Saidova, 1975

Genus Rumanoloculina Neagu, 1984

Rumanoloculina robusta (Neagu), 1968 (Pl. 5, Fig. 10)
Quinqueloculina robusta Neagu, 1968, p. 566, pl. 1, figs. 8-17; pl. 7, figs. 1-3 Rumanoloculina robusta Neagu, 1986, p. 315, pl. 7, figs. 23-25; pl. 8, figs. 30-38; text-fig. 2

Description. Test large, globular. Chambers quinqueloculine in arrangement, forming successive Y-shaped cycles less than $90^{\circ}$ apart, with floors; five chambers visible externally, three on one side, two on the opposite, separated by depressed sutures. Wall calcareous, imperforate, porcelaneous. Aperture indistinct.

Remarks. About 15 specimens were observed in thin section.

Age and occurrence. Aptian; MIT Guyot from Samples 144-878A-45M-

$3,123-125 \mathrm{~cm},-53 \mathrm{R}-4,54-55 \mathrm{~cm}$, and $-54 \mathrm{R}-5,98-102 \mathrm{~cm}$

Known range. Berriasian to early Aptian

Geographic distribution. This species, originally described from the Barremian of Romania, is known along the margins of Tethys.

Genus Istriloculina Neagu, 1984

Istriloculina sp. cf. I. granumtrici (Iovcheva), 1962

$$
\text { (Pl. 5, Figs. 14-17) }
$$

Description. Test elongate, ovate. Chambers arrangement Y-shaped, without floors; three chambers are visible externally, two chambers on one side, and one on the opposite, separated by slightly depressed sutures. Wall very thin, calcareous, imperforate, porcelaneous. Aperture indistinct.

Remarks. More than 20 specimens observed in thin section. I. granumtrici was identified from whole specimens; it is difficult to compare to our specimens in thin section, but sections display the same size. Species of Istriloculina are widespread in restricted Cretaceous environments and are generally attributed to the genus Pseudotriloculina Cherif, 1970 (e.g., Arnaud Vanneau, 1980). This taxonomic assignment is incorrect, however, and the Cretaceous forms are now assigned to Istriloculina, a genus described by Neagu (1984).

Age and occurrence. late Aptian; Takuyo-Daisan Guyot from Sample 144-879A-15R-1, 35-37 cm

Known range. early Aptian

Geographic distribution. This species was described from the lower Aptian of Romania.

$$
\begin{gathered}
\text { Genus Axiopolina Neagu, } 1984 \\
\text { Axiopolina? sp. } \\
\text { (Pl. 5, Fig. 13) }
\end{gathered}
$$

Description. Test minute, elongate. Chambers initially in milioline arrangement, then form Y-shaped pattern, with well-developed chamber floors, separated by strongly depressed sutures. Wall calcareous, imperforate, porcelaneous. Aperture indistinct.

Remarks. Four specimens observed in thin section.

Age and occurrence. late Albian; MIT Guyot from Sample 144-878A14R-1, 14-18 cm; Takuyo-Daisan Guyot from Samples 144-879A-2R-1, $132-138 \mathrm{~cm}$, and $-5 \mathrm{R}-1,53-58 \mathrm{~cm}$

$$
\begin{gathered}
\text { Subfamily SIGMOILINITINAE Luczkowska, } 1974 \\
\text { Genus Pseudonummoloculina Calvez, } 1988 \\
\text { Pseudonummoloculina aurigerica Calvez, } 1988 .
\end{gathered}
$$$$
\text { (PI. 5, Fig. 9) }
$$

Pseudonummoloculina aurigerica Calvez, 1988, pp. 392-395, pl. 1, figs. 1-18; text-fig. 3

Description. Test discoidal. Protoconch surrounded entirely by flexostyle canal, followed by milioline stage, then becomes nearly planispiral, final whorl with four to five chambers. Wall calcareous, porcelaneous. Aperture probably areal.

Remarks. A single specimen was observed in thin section.

Age and occurrence. middle to late(?) Albian; MIT Guyot from Sample $144-878 \mathrm{~A}-23 \mathrm{M}-1,22-25 \mathrm{~cm}$

Known range. early to middle Albian

Geographic distribution. This species was described from the Albian of the Pyrenees and identified in Mexico.

$$
\begin{gathered}
\text { Subfamily FISCHERINIDAE Millett, } 1898 \\
\text { Genus Fischerina Terquem, } 1878 \\
\text { Fischerina? carinata Peybernès, } 1984
\end{gathered}
$$$$
\text { (Pl. 5, Figs. 18, 19) }
$$

Fischerina carinata Peybernès, 1984,pp. 494-498, pl. 2, figs. 1-15; text-fig. 2

Description. Test discoidal, evolute, periphery slightly carinate. Protoconch surrounded entirely by flexostyle canal, followed by three whorls with 
up to six chambers, partially overlapping. Wall calcareous, porcelaneous, thick. Aperture at open end of final chamber.

Age and occurrence. late Albian; Takuyo-Daisan Guyot from Samples 144-879A-5R-1, 73-78 cm, -6R-1, 12-16 cm, and -6R-1, 19-24 cm

Known range. late Albian

Geographic distribution. This species was described from the upper Albian of southwestern France.

$$
\begin{gathered}
\text { Incertae sedis } \\
\text { Genus Tubiphytes } \\
\text { Tubiphytes sp. } \\
\text { (Pl. 5, Figs. 11, 12) }
\end{gathered}
$$

Description. Test elongate, tubular, more or less ovate in section. Interior nonseptate. Wall thick, agglutinated, of variable thickness, calcareous, imperforate. Aperture indistinct.

Remarks. The same species was observed in the Aptian of central Italy. It is only present in carbonate clasts from the volcanic breccia at MIT Guyot.

Age and occurrence. Aptian; MIT Guyot from Samples 144-878A-55R-3, $46-49 \mathrm{~cm},-56 \mathrm{R}-3,135-137 \mathrm{~cm},-58 \mathrm{R}-7,47-49 \mathrm{~cm}$, and $-60 \mathrm{R}-2,23-27 \mathrm{~cm}$

\section{SUCCESSION AND AGE OF BENTHIC FORAMINIFER ASSEMBLAGES}

The presence of planktonic foraminifers and nannofossils at the very top and bottom of the carbonate platform at MIT and TakuyoDaisan Guyots constrains the time of deposition (Tables 1,2). At MIT Guyot, the carbonate sedimentation occurred during the early Aptian and ended in the late Albian; at Takuyo-Daisan Guyot, it occurred during the late Aptian and ended probably in a late Albian (Erba et al., this volume). These data confirm the age determinations based on benthic foraminifers made aboard the JOIDES Resolution (Sites 878 and 879; Premoli Silva, Haggerty, Rack, et al., 1993).

In this study, carbonate platform microfaunas are subdivided into seven benthic foraminifer assemblages that aid in subdividing the carbonate platform sequences.

\section{Assemblage 0}

Species. Nezzazata isabellae, Cuneolina sliteri n. sp., Cuneolina parva, Cuneolina sp. cf. C. pavonia, Fischerina? carinata, Trocholina altispira, Paracoskinolina sp. cf. P. sunnilandensis, Orbitolina (Orbitolina) sp., Orbitolina (Conicorbitolina) sp. cf. O. (C.) aliensis.

Range. From Samples 144-879A-1R-1, 23-25 cm, to -5R-1, 73-78 cm

Age. latest Albian?

This assemblage was recovered only from the topmost part of the platform at Site 879. Subgenera Orbitolina and Conicorbitolina of the genus Orbitolina are widespread in the latest Albian and early to middle Cenomanian (Moullade et al., 1985; Schroeder and Neumann, 1985). But species described in Assemblage 0 have never been well identified and cannot be compared to the previous described species. Trocholina altispira is described from the upper Albian to the lower Cenomanian of the Middle East (Henson, 1947), whereas Fischerina? carinata is described from the upper Albian of the Pyrenees (Peybernès, 1984). The association of Orbitolina, Conicorbitolina, Trocholina altispira, and Fischerina? carinata indicate the latest Albian. This age is consistent with that inferred from planktonic foraminifers. In fact, the presence of a specimen close to Rotalipora ticinensis in Sample 144-879A-2R-1, 132-138 cm (Erba et al., this volume) would indicate a late Albian age ranging from the Rotalipora ticinensis Zone to the lower half of the Rotalipora appenninica Zone.

Assemblage 0 was recovered elsewhere only from dredges at Daiichi-Kashima Seamount. The absence of this assemblage from other sites in the Pacific basin including MIT may be explained as follows:

1. The youngest Albian shallow-water sediments are only preserved at Site 879 (Takuyo-Daisan) and Daiichi-Kashima Seamount.

2. Depositional environments are unique at Site 879 because of the location of the drill site on the windward margin of the guyot. A similar assemblage, however, was never dredged from the margins of other guyots, except at Daiichi-Kashima (also in the Japanese Group).

3. The diagnostic species appear earlier in the Pacific area than in other regions.

This hypothesis may explain why the Sr-isotope age for TakuyoDaisan Guyot is older than that for MIT Guyot (Wilson et al., this volume), but it does not explain why the microfauna is missing at MIT.

The lack of recovery below Assemblage 0 (Fig. 2) prevents us from confirming the youngest age of the topmost sediments at Takuyo-Daisan Guyot as the benthic foraminifer succession is unknown. The only stratigraphic evidence at present is that this assemblage is missing at MIT.

\section{Assemblage I}

Species. Nezzazata isabellae, Cuneolina sliteri n. sp., Cuneolina parva, Cuneolina sp. cf. C. pavonia, Pseudonummoloculina sp.

Range. From Samples 144-878A-1R-1, 28-31 cm, to -5R-1, 28-31 cm

Age. late Albian

Large cuneolinids like Cuneolina parva or Cuneolina pavonia are known in the late Albian, according to the participants of the IGCP 262 Working Group on Large Foraminifers (unpubl. data). Pseudonummoloculina sp. is close to specimens from the Albian of Texas, described as Nummoloculina heimi by Conkin and Conkin (1958). For all these reasons, we think that this assemblage belongs to the late Albian. This stratigraphic attribution is confirmed by the presence of a possible individual of Rotalipora subticinensis (Sample 144-878A$3 \mathrm{R}-1,40-46 \mathrm{~cm}$ ) identifying the nominal subzone of the upper Biticinella breggiensis Zone (Erba et al., this volume).

\section{Assemblage II}

Species. Nezzazata isabellae, Cuneolina sliteri n. sp., Cuneolina parva, Pseudonummoloculina aurigerica, Arenobulimina sp. cf. A. chapmani Range. From Samples 144-878A-6R-1, 8-11 cm, to -24M-1, 0-2 cm Age. late Albian

Cuneolina parva is considered a late Albian species and Pseudonummoloculina aurigerica has been described from the middle Albian of the Pyrenees. The presence of Cuneolina parva suggests a late Albian age for this assemblage.

\section{Assemblage III}

Species. Nezzazata isabellae, Cuneolina sliteri n. sp, Orbitolina (Mesorbitolina) texana oculata, Voloshinoides? sp. C, Coskinolinella navarrensis

Range. From Samples 144-878A-25M-1, 0-3 cm, to -38M-1, 13-17 cm

Age. middle to late? Albian

Orbitolina (Mesorbitolina) texana oculata was described from the middle Albian of Texas (Douglass, 1960) and is known from the lower to middle Albian. The known range of Coskinolinella navarrensis found at the top of this assemblage is from the upper middle Albian to the lowermost upper Albian (Cherchi, in Schroeder and Neumann, 1985). For these reasons, this assemblage is attributed to the middle Albian, although it may be as younger as lowermost upper Albian. Rare planktonic foraminifers were observed and may also indicate a lower upper Albian age (Sample 144-878A-26M-1, 4-12 $\mathrm{cm}$; see Erba et al., this volume).

\section{Assemblage IV}

Species. Cuneolina sliteri n. sp., Orbitolina (Mesorbitolina) sp.cf. O. (M.) pervia, Voloshinoides? sp. C, Coskinolinella daguini

Range. From Section 144-878A-39M-1, 13-21 cm, to $-42 \mathrm{M}-1,15-20 \mathrm{~cm}$ Age. Late Aptian to early Albian 
Orbitolina (Mesorbitolina) pervia was described from the lower Albian of Texas (Douglass, 1960) and is known from the middle Aptian (middle Gargasian; N'Da, 1984) to the lower Albian in different countries of the Tethys. The range of Coskinolinella daguini is from the upper Aptian to the lower Albian (Cherchi, in Schroeder and Neumann, 1985). The samples coming from Cores 144-878A-41M and $-42 \mathrm{M}$ contain planktonic foraminifers and calcareous nannofossils of the Nannoconus truittii Acme from the middle Aptian. This age determination defines the age at the bottom of this interval. The age of Assemblage IV is considered late Aptian (middle Gargasian to Clansayesian) to early Albian.

At Takuyo-Daisan, the same Nannoconus truittii assemblage is known at the bottom of Hole 879A. The interval from Sample 144$879 \mathrm{~A}-14 \mathrm{R}-1,13-18 \mathrm{~cm}$, to $-18 \mathrm{R}-1,22-26 \mathrm{~cm}$, contains benthic foraminifers related to faunal Assemblage IV, but the two significant species of this assemblage are missing. The species Nezzazata sp. B and Arenobulimina sp. A found in this interval are known either at the bottom of Hole 865A (Allison Guyot) or rarely in Assemblage V. The most interesting and surprising species found at the bottom of Site 879 is a species close to Trocholina odukpaniensis (Samples 144879A-16R-1, 109-112 cm, and -16R-1, 131-135 cm). Trocholina was previously unreported from the upper Aptian to middle Albian.

\section{Assemblage V}

Species. Vercorsella sp. cf. V. immaturata, Nezzazata? sp. C, Valvulineria? n. sp. 1, Voloshinoides? sp. D, Arenobulimina sp. A, Ammobaculites celatus.

Range. From Samples 144-878A-42M-1, 26-32 cm, to -70R-1, 12-15 cm Age. early late Aptian

Nezzazata sp. B and Arenobulimina sp. A found rarely in this interval are known in the upper Aptian of the Aquitaine Basin (N'Da, 1984). Voloshinoides? sp. D (figured by N'Da, 1984) is known from the lower part of the upper Aptian of the Aquitaine Basin (Gargasian); Ammobaculites celatus, however, was described from the lower Aptian of Vercors, France (Bedoulian). Nevertheless, the assemblage is dominated by upper Aptian microfauna and would belong to the early late Aptian (Gargasian) to be consistent with the age of the previous assemblage.

\section{Assemblage VI}

Species. Nezzazata? sp. C., Valvulineria? n. sp. 1, Neotrocholina sp. cf. $N$. infragranulata

Range. From Samples 144-878A-70R-1, 54-57 cm, to -78R-1, 20-25 cm Age. early Aptian

This assemblage is very sparse, and only the presence of Neotrocholina sp. cf. N. infragranulata (Samples 144-878A-74R-1, 6-10 $\mathrm{cm}$, and $-75 \mathrm{R}-1,141-143 \mathrm{~cm}$ ) indicates that this faunal assemblage belongs to the lower Aptian (Bedoulian). According to the participants of the Working Group on Large Foraminifera IGCP Project 262 (unpubl. data, 19XX), representatives of the genus Neotrocholina disappeared at the Bedoulian/Gargasian boundary. Fortunately, calcareous nannofossils found in Sections 144-878A-77R-1 and -75R-1 identify the Chiastozygus litterarius Nannofossil Zone of early Aptian age.

A seventh assemblage of early Aptian age was identified as mixed within Assemblage V of late Aptian age in the polymictic breccia recovered from Cores $144-878 \mathrm{~A}-44 \mathrm{R}$ to $-65 \mathrm{R}$. This assemblage is characterized by abundant, well-preserved dasycladacean algae (Masse and Arnaud Vanneau, this volume) which are missing in the coeval Assemblage VI described above. Lower Aptian carbonate clasts seem more numerous at the top of the breccia unit, while upper Aptian clasts yielding Assemblage V are present throughout the whole unit.

\section{Summary}

In conclusion, benthic foraminiferal assemblages are used to subdivide the carbonate sequence at MIT and Takuyo-Daisan guyots into seven intervals ranging in age from late Albian to early Aptian.

At Takuyo-Daisan Guyot, the topmost Assemblage 0 indicates the latest Albian, and species in the bottom assemblage are rare but suggest a late Aptian age. A gap may be present between the upper Aptian and the uppermost Albian, but this is inferred only from the thickness of the carbonate section (less than half the MIT Guyot section) and is not well established because of the poor recovery.

The lower Aptian carbonate clasts within the volcanic breccia at MIT Guyot (Site 878) display shallow-water carbonate facies different from those recovered at the drill site below the breccia. These different, but at least partially coeval, facies may be interpreted as having been formed in other parts of the lower Aptian carbonate platform on MIT Guyot and resedimented at the site location by the phreatomagmatic episode (see Premoli Silva, Haggerty, Rack, et al., 1993).

\section{CORRELATION WITH OTHER PACIFIC AND TETHYAN REGIONS}

Previously, only a few Cretaceous benthic foraminifers have been described from the Pacific guyots, and specific determinations are rare. Many authors mention Orbitolina but without taxonomic precision.

Faunal Assemblage 0, as defined in this paper, is probably present on the top of Daiichi-Kashima. Shiba (1988, pl. 7) identified "Orbitolina lenticularis" (Blumenbach) Form-group II and III Hofker (probably $=$ Conicorbitolina) and Cuneolina laurentii (probably = Cuneolina parva) in dredges from this seamount. This assemblage is similar to that found at the top of Takuyo-Daisan Guyot.

Grötsch (1991, pl. 19, figs. 3-9) and Grötsch et al. (1993, fig. 5B-E) described Cuneolina pavonia (probably includes both Cuneolina parva and Cuneolina sp. cf. C. pavonia) from dredges of MIT Guyot. These species are components of Assemblage I. The same assemblage occurs at the top of the Resolution and Allison guyots (Arnaud Vanneau and Sliter, 1995). Therefore, it seems likely that upper Albian carbonate platform sedimentation ceased later in the Japanese Group than at other Pacific guyots, based on the presence of the Assemblage 0 .

The Aptian to Albian carbonate sequence is very complete at MIT Guyot, and the thickness is relatively very large even taking into account the $200 \mathrm{~m}$ of interbedded volcaniclastic breccia. None of the Aptian to Albian carbonate platforms drilled on guyots during Legs 143 and 144 show the same thickness for the same time span. Thus, correlations from one site to another are difficult. Gaps probably exist and will be established when precise correlations between all sites are completed (A. Arnaud Vanneau and W.V. Sliter, unpubl. data).

Species from Sites 878 and 879 were partly described by Arnaud Vanneau and Sliter (1995) for Leg 143, although the Aptian-Albian species are more numerous in samples from Leg 144 described herein. As indicated by Arnaud Vanneau and Sliter (1995), there are only a few endemic species present. This observation probably results from the lack of micropaleontological reports coming from countries surrounding the Pacific Ocean.

The present microfauna includes a mixture of species well known along the margins of the Tethys such as Praechrysalidina sp. cf. $P$. infracretacea and Trocholina altispira from the southern margin, and Pseudonummoloculina aurigerica, Coskinolinella navarrensis, Coskinolinella daguini, and Fischerina? carinata from the northern margin. There are also species that are known in the American area, like Orbitolina (Mesorbitolina) texana oculata, Paracoskinolina sp. cf. P. sunnilandensis, and probably Orbitolina (Mesorbitolina) sp.cf. $O$. (M.) pervia, but these species are distributed worldwide as well. 


\section{ENVIRONMENTS AND PALEOECOLOGY}

Three major ecological associations of foraminifers are present: encrusting foraminifers such as Bdelloidina sp. cf. B. urgonensis in coarse and ooid sands; textulariids, miliolids, nezzazatids, and cuneolinids in lagoonal environments; and Istriloculina and Glomospira in muddy and restricted environments. Orbitolinids occur either with wave-resistant species in coarse sand or during a rise of sea level in lagoon. Foraminifers are rarely abundant except in orbitolinid facies. They are poorly diversified except during periods associated with sea-level rise.

Environments are different at MIT and Takuyo-Daisan guyots. At Takuyo-Daisan (Table 3), two types of environments are identified. At the bottom, the carbonate environment corresponds to the period when the guyot was flooded and when the first carbonate sediments covered the volcanic substrate (from Samples 144-879A-10R-1, 11$15 \mathrm{~cm}$, to $-17 \mathrm{R}-2,92-98 \mathrm{~cm}$ ). This transgressive facies was deposited in a very shallow-water environment, and the microfacies contains wood fragments, small lava fragments, and broken and worn bioclasts, associated with many arthropod fragments (from Samples 144-879A-16R-1, 19-22 cm, to -17R-2, 49-54 cm). The in situ benthic foraminifers are small in size and are mostly represented by small-sized Nezzazata and Arenobulimina (Samples 144-879A-14R$1,13-18 \mathrm{~cm}$, to $-17 \mathrm{R}-1,40-46 \mathrm{~cm}$ ). Above this interval, the carbonate recovery corresponds to a very different environment (from Samples 144-879A-1R-1, 123-125 cm, to - 16R-1, 19-24 cm). Sediments consist of coarse sand composed of coral, echinoid, rudist and large bivalve fragments, and oncoids. The bivalve fragments are associated with incrusting foraminifers such as Bdelloidina $\mathrm{sp}$. cf. B. urgonensis (Sample 144-879A-3R-1, 42-47 cm) and encrusting algae such as Polystrata alba (Sample 144-879A-3R-1, 42-47 cm). There are also large-sized dasycladacean algae such as Neomeris cretacea (Samples 144-879A-1R-1, 23-25 cm, to -2R-1, 129-131 cm) (Masse and Arnaud Vanneau, this volume); large flat or high conical orbitolinids, such as Orbitolina (Orbitolina) sp. and Orbitolina (Conicorbitolina) sp. cf. O. (C.) aliensis; and cuneolinids, such as Cuneolina parva and Cuneolina sp. cf. C. pavonia (Samples 144-879A-1R-1, 23-25 cm, to $-5 \mathrm{R}-1,73-78 \mathrm{~cm}$ ).

The hole at Takuyo-Daisan was drilled on the margin of the guyot in a windward position. This location explains the size of the sand grains and the presence of large and wave-resistant foraminifers, such as encrusting foraminifers and large conical orbitolinids, which are associated with encrusting algae and large-sized dasycladacean algae.

At MIT Guyot, the environments are more diverse (Table 4). At the bottom, the lower carbonate platform sequence is mostly represented by sediments deposited in an open lagoon (Samples 144 $878 \mathrm{~A}-66 \mathrm{R}-1,33-37 \mathrm{~cm}$, to $-72 \mathrm{R}-1,0-5 \mathrm{~cm}$ ) with normal salinity and probably above wave base (Table 4 ). Sediments are coarser and composed of ooid sands, consisting of bivalve, coral, calcareous sponge, and echinoid fragments. Microfauna and algae are rare except for representatives of encrusting algae or encrusting foraminifers such as Polystrata alba and Bdelloidina sp. cf. B. urgonensis. At the very bottom, deeper environments are identified by the presence of Marssonella (Samples 144-878A-75R-1, 46-50 cm, to -76R-1, 25$32 \mathrm{~cm}$ ), Nodosariidae (Samples 144-878A-75R-1, 46-50 cm, -72R-1, 0-5 cm), bryozoans, and few planktonic foraminifers (Sample 144$878 \mathrm{~A}-75 \mathrm{R}-1,46-50 \mathrm{~cm}$ ). These observations indicate that after a period of maximum flooding (Sample 144-878A-75R-1, 46-50 cm), the space available is progressively filled by ooid sands indicating normal marine salinity and oxygenation conditions and deposition above wave base.

In the upper carbonate sequence above volcanic breccias, normal lagoonal microfacies with abundant to common bivalve fragments (including rudists) and a few echinoid fragments are well represented. Miliolids, textulariids, and cuneolinids are present and are sometimes common to abundant. Valvulineria? and Nezzazata are always present and abundant. Rising sea level is suggested by the presence of either large sponge spicules (Samples 144-878A-15R-1, 7-10 cm, to -20R$1,0-3 \mathrm{~cm}$ ) or a few planktonic foraminifers (Sample 144-878A-3R-1, $40-46 \mathrm{~cm}$ ). During high sea level, the microfacies changes completely and the microfauna is largely dominated by orbitolinids (Samples $144-878 \mathrm{~A}-30 \mathrm{M}-1,11-18 \mathrm{~cm}$, to $-31 \mathrm{M}-1,37-44 \mathrm{~cm}$ ) and common echinoid fragments.

Very restricted shallow-water environments occur during the upper half of the carbonate platform deposition (from Samples 144$878 \mathrm{~A}-4 \mathrm{R}-1,41-47 \mathrm{~cm}$, to $-24 \mathrm{M}-1,0-2 \mathrm{~cm}$ ). They are represented by microfacies characterized by strong microbial activity and the presence of Cayeuxia. The sediment is a mudstone that contains mostly small-sized gastropods, abundant ostracodes, and mud-dwelling foraminifers such as Istriloculina and Glomospira. Indications of a rare fresh-water environment are limited to MIT Guyot, where a charophyte oogonium (Sample 144-878A-21R-1, 8-12 cm) was found but is presumably reworked.

To summarize, depositional environments are different at the two sites except for the initial period of carbonate sedimentation on the volcanic island. This environment is represented by the first shallowwater carbonates mixed with volcanic fragments and associated with small-sized Nezzazata or Valvulineria? and Arenobulimina. On the windward margin of Taikuyo-Daisan where Site 879 was drilled, only coarse sand composed of coral debris and wave-resistant foraminifers and algae was recovered. At the center of MIT Guyot, where Site 878 was drilled, the evolution is more complex. This locality shows openmarine lagoonal environments at the bottom and then, after the volcanic episode, the appearance of normal (rudist and miliolid) lagoonal conditions interspersed with restricted environments. Periods of rising sea levels are indicated by the occurrence of planktonic foraminifers, small-sized ammonites, bryozoans, large sponge spicules, and orbitolinids. The presence of lower Aptian carbonate clasts showing lagoonal to restricted environments within the interbedded volcanic breccia at Hole $878 \mathrm{~A}$ attests to the existence of fossil lagoonal sediments, which were partly destroyed during the volcanic episode.

\section{CONCLUSIONS}

Fourteen species of Aptian and Albian benthic foraminifers from shallow-water carbonates are described for the first time from the Pacific Ocean at MIT and Takuyo-Daisan guyots. The fauna represents a mixture of species known from the northern and southern margins of the Tethys and from America and contains few endemic species. The fauna is neither abundant nor diverse and the low diversity is not readily explained. The position of the guyots close to the paleoequator may explain this sparse microfauna but, also, the isolated position of guyots in an oceanic setting means that not all the Tethyan microfauna would be able to migrate to the guyots (M. Simmons, pers. observ., 1994).

Foraminifers are represented by six major groups: encrusting foraminifers, miliolids, textulariids, nezzazatids, cuneolinids, and the orbitolinids. Encrusting foraminifers and high conical orbitolinids are associated with coarse sands. Miliolids, textulariids, nezzazatids, and cuneolinids are present in shallow-water and lagoonal environments, and muddy, restricted environments are characterized by Istriloculina and Glomospira. Orbitolinids occur during rising sea levels and are probably associated with transgressive trends, as we have observed in other Tethyan areas. Maximum flooding is not always indicated by a complete change of facies, but rather by the presence of sponge spicules, planktonic foraminifers and, sometimes, ammonites.

We have identified seven benthic foraminifer associations from the Aptian to Albian. At MIT Guyot (Site 878), there are six faunal assemblages: I and II, occurring in the late Albian; III, in the middle Albian; IV, in the uppermost late Aptian and/or early Albian?; V, in the late Aptian; and VI, in the early Aptian. Carbonate clasts from the volcanic breccia at MIT Guyot contain a mixture of early Aptian and late Aptian assemblages. At Takuyo-Daisan Guyot (Site 879), there are only two faunal Assemblages: 0 occurring in the latest Albian, and 
$\mathrm{V}$ in the late Aptian. A hiatus may occur between the late Aptian and the latest Albian at this site.

Carbonate platform deposits do not begin and end at the same time on the two guyots. At MIT Guyot, the initial sediments are older (early Aptian) than at Takuyo-Daisan Guyot (late Aptian), whereas the cessation of carbonate platform sedimentation during the late Albian is apparently earlier at MIT Guyot than at Takuyo-Daisan Guyot.

\section{ACKNOWLEDGMENTS}

The authors thank Dr. William V. Sliter, who made valuable suggestions concerning micropaleontology systematics and editorial help. The senior author is indebted to Martine Argot, who perfected a new technique for disaggregating the carbonate sediment and isolating the benthic foraminifers. E. Fourcade and M. Simmons are thanked for their critical reading of the manuscript.

\section{REFERENCES*}

Arnaud Vanneau, A., 1980. Micropaléontologie, paléoécologie et sédimentologie d'une plate-forme carbonatée de la marge passive de la Téthys: l'Urgonien du Vercors septentrional et de la Chartreuse (Alpes occidentales). Geol. Alp., Mem. 11.

Arnaud Vanneau, A., and Boisseau, T., 1988. Le genre Trocholina Paalzow 1922 et ses principales espèces au Crétacé. Benthos '86. Spec. Publ. Rev. Paleobiol., 2:353-377.

Arnaud Vanneau, A., and Chiocchini, M., 1985. Révision de Sabaudia minuta. In Schroeder, R., and Neumann, M. (Eds.), Les Grandes Foraminiferes du Crétacé Moyen de la Région Méditerranéenne. Geobios Mem. Spec., 7:29-32.

Arnaud Vanneau, A., and Sliter, W.V., 1995. Early Cretaceous shallow-water foraminifers and fecal pellets from Leg 143 compared with coeval faunas from the Pacific Basin, Central America, and the Tethys. In Winterer, E.L., Sager, W.W., Firth, J.V., and Sinton, J.M. (Eds.), Proc. ODP, Sci. Results, 143: College Station, TX (Ocean Drilling Program), 537-564.

Banner, F.T., Simmons, M.D., and Whittaker, J.E, 1991. The Mesozoic Chrysalidinidae (Foraminifera, Textulariacea) of the Middle East: the Redmond (Aramco) taxa and their relatives. Bull. Br. Mus. (Nat. Hist.), Geol., 47:101-152.

Calvez, H., 1988. Pseudonummoloculina aurigerica n. gen., n. sp. et Dobrogelina? angulata n. sp., deux foraminiferes nouveaux de l'Albien calcaire des Pyrénées franco-espagnoles. In Benthos '86. Spec. Publ. Rev. Paleobiol., 2:391-399.

Charollais, J., and Brönnimann, P., 1965. Première note sur les foraminiferes du Crétacé inférieur de la région genevoise. Sabaudia Charollais et Brönnimann, n. gen. Arch. Sci., 18:615-624.

Conkin, J.E., and Conkin, B.M., 1958. Revision of the genus Nummoloculina and emendation of Nummoloculina heimi Bonet. Micropaleontology, 4:149-158.

Cushman, J.A., 1936. New genera and species of the families Vemeuilinidae and Valvulinidae and of the subfamily Virgulininae. Spec. Publ. Cushman Lab. Foraminiferal Res., 6:1-71.

De Castro, P., 1963. Cuneolina scarsellai n. sp. nel Cretacico dell'Appennino meridionale. Boll. Soc. Nat. Napoli, 72:71-76.

Delmas, M., and Deloffre, R., 1961. Découverte d'un nouveau genre d'Orbitolinidae dans la base de l'Albien en Aquitaine. Rev. Micropaleontol., $4: 167-172$.

Dessauvagie, T.F.J., 1968. Cenomanian Trocholina from Nigeria. Micropaleontology, 14:64-72.

d'Orbigny, A., 1846. Foraminiferes Fossiles du Bassin Tertiaire de Vienne: Paris (Gide et Comp.).

Douglass, R.C., 1960. The foraminiferal genus Orbitolina in North America. Geol. Surv. Prof. Pap. U.S., 333:1-52.

Fourcade, E., Raoult, J.F., and Vila, J.M., 1972. Debarina hahounerensis n. gen., n. sp., nouveau lituolidé (Foraminifère) du Crétacé inférieur constantinois. C. R. Acad. Sci. Ser. 2, 274:191-193.

Görog, A., and Arnaud Vanneau, A., in press. Lower Cretaceous Orbitolinas from Venezuela. Micropaleontology.

\footnotetext{
-Abbreviations for names of organizations and publications in ODP reference lists follow the style given in Chemical Abstracts Service Source Index (published by American Chemical Society).
}

Grötsch, J., 1991. Die Evolution von Karbonatplattformen des offenen Ozeans in der mittleren Kreide (NW-Jugoslawien, NW-Pazifik, NW-Griechenland): Möglichkeiten zur Rekonstruktion von Meeresspeigeländerungen verschiedener Grössenordnung [Doctoral dissert.]. Erlangen-Nürnberg Univ., Germany.

Grötsch, J., and Flügel, E., 1992. Facies of sunken Early Cretaceous atoll reefs and their capping late Albian drowning succession (northwestern Pacific). Facies, 27:153-174.

Grötsch, J., Schroeder, R., Noé, S., and Flügel, F., 1993. Carbonate platforms as recorders of high-amplitude eustatic sea-level fluctuations: the late Albian appenninica event. Basin Res., 5:197-212.

Hamilton, E.L., 1956. Sunken islands of the Mid-Pacific Mountains. Mem.Geol. Soc. Am., 64.

He, Y., 1982. Some Mesozoic foraminifera from Xizang. In The Series of the Scientific Expedition to the Quinghai-Xizang Plateau-Paleontology of Xizang: Beijing (Science Press), 4:33-50.

Henson, F.R.S., 1947. Foraminifera of the genus Trocholina in the Middle East. Ann. Mag. Nat. Hist., Ser. 11, 14:445-459.

1948. New Trochamminidae and Verneuilinidae from the Middle East. Ann. Mag. Nat. Hist., Ser. 11, 14:605-630.

Hofker, J., Jr., 1965. Some foraminifera from the Aptian-Albian passage of northern Spain. Leidse Geol. Meded., 33:183-189.

Iovcheva, P.M., 1962. Foraminifera of the oolitic limestone of the Aptian along the Rusenski Low River. Spis. Bulg. Geol. Druzh., 23:41-61.

Konishi, K., 1989. Limestone of the Daiichi Kashima Seamount and the fate of a subducting guyot: fact and speculation from the Kaiko "Nautile" dives. Tectonophysics, 160:249-265.

Laug, B., and Peybernès, B., 1979. Daxia minima nov. sp. Lituolidé nouveau de l'Aptien Basco-Béarnais. Geobios, 12:717-723.

Loeblich, A.R., Jr., and Tappan, H., 1988. Foraminiferal Genera and Their Classification: New York (Van Nostrand Reinhold).

Luperto Sinni, E., 1979. Praechrysalidina infracretacea n. gen., n. sp. (Foraminiferida) del Cretaceo inferiore delle Murge Baresi. Studi Geol. Morfol. Regione Pugliese, 5:3-16.

Magniez, F., 1972a. Spiroplectamminoides, nouveau genre de foraminifere des Formations Para-Urgoniennes Cantabriques (Espagne). Rev. Esp. Micropaleontol., 30:179-198.

- 1972b. Novalesia nouveau nom pour le genre de foraminifere Spiroplectamminoides Magniez 1972. Rev. Esp. Micropaleontol., 6:155.

Maync, W., 1955. Coskinolina sunnilandensis, n. sp., a Lower Cretaceous (Urgo-Albian) species. Contrib. Cushman Found. Foraminiferal Res., 6:105-111.

Michaud, F., and Fourcade, E., 1989. Stratigraphie et paléogéographie du Jurassique et du Crétacé du Chiapas (Sud-Est du Mexique). Bull. Soc. Geol. Fr., Ser. 8, 5:639-650.

Moullade, M., Bernard, P., Rey, J., and Saint-Marc, P., 1985. Biostratigraphic interest and paleobiogeographic distribution of early and mid-Cretaceous Mesogean Orbitolinids (Foraminifera). J. Foraminiferal Res., 15:149-158.

N'Da, L., 1984. Urgonien des Pyrénées occidentales: synthèse paléo-écologique, micropaléontologique et paléogéographique [Thèse de 3ème cycle]. Univ. Pau.

Neagu, T., 1968. Study of the Miliolidaceae in the lower Cretaceous (Barremian) of Southern Dobrogea. Travaux, Mus. Hist. Nat. "Grigore Antipa," 8:563-572.

_ 1984. Nouvelles données sur la morphologie du test, sur la systématique et la nomenclature des miliolidés agastisthègues du Mésozoïque. Rev. Esp. Micropaleontol., 16:75-90.

, 1986. Barremian-lower Aptian miliolid fauna in Southern Dobrogea. Rev. Esp. Micropaleontol., 18:313-348.

Noth, R., 1951. Foraminiferen aus Unter und Oberkreide des österreichischen auteils an flysch, helvetikum und vorland vorkommen. Jahrb. Geol. Bundesanst. Austria, 3:1-91.

Peybernès, B., 1984. Foraminifères benthiques nouveaux de l'Albien supérieur du Massif du Turbon (Pyrénées espagnoles). In Oertli, H.J. (Ed.), Benthos '83. Bull. Cent. Rech. Explor.-Prod. Elf-Aquitaine, Mem., 6:491499.

Premoli Silva, I., Haggerty, J., Rack, F., et al., Proc. ODP, Init. Repts., 144: College Station, TX (Ocean Drilling Program).

Ramirez del Pozo, J., 1971. Bioestratigrafia y microfacies del Jurasico y Cretacico del Norte de Espana (Region cantabrica). Mem., Inst. Geol. Min. Esp., 78.

Research Group for the Daiichi-Kashima Seamount, 1976. Topography and geology of the Daiichi-Kashima Seamount, off Inubo Cape, southeastern Honshu, Japan. Earth Sci., 30:222-240. 
Schlager, W., and Philip, J., 1990. Cretaceous carbonate platform. In Ginsburg, R.N., and Beaudoin, B. (Eds.), Cretaceous Resources, Events and Rhythms: Dordrecht (Kluwer), NATO ASI Ser. C, 304:173-195.

Schroeder, R., and Neumann, M. (Eds.), 1985. Les Grandes Foraminiferes du Crétacé Moyen de la Région Méditerranéenne. Geobios, Spec. Mem., 7.

Shiba, M., 1979. Geological history of the Yabe Guyot to the east of the Ogasawara Islands. J. Geol. Soc. Jpn., 85:209-220.

1988. Geohistory of the Daiichi-Kashima seamount and the Middle Cretaceous eustacy. Sci. Rep. Nat. Hist. Mus., Tokai Univ., 2.

Wernli, R., and Schulte, S., 1993. "Bdelloidina urgonensis" n. sp., un foraminifere constructeur de biohermes dans l'Urgonien de Haute-Savoie (France). Eclogae Geol. Helv., 86:529-541.
Zhang, B., 1982. Orbitolina (Foraminifera) from Xizang. In The Series of the Scientific Expedition to the Quinghai-Xizang Plateau-Palaeontology of Xizang: Beijing (Science Press), 4:51-80.

Date of initial receipt: 15 February 1994

Date of acceptance: 28 July 1994

Ms 144SR-002 

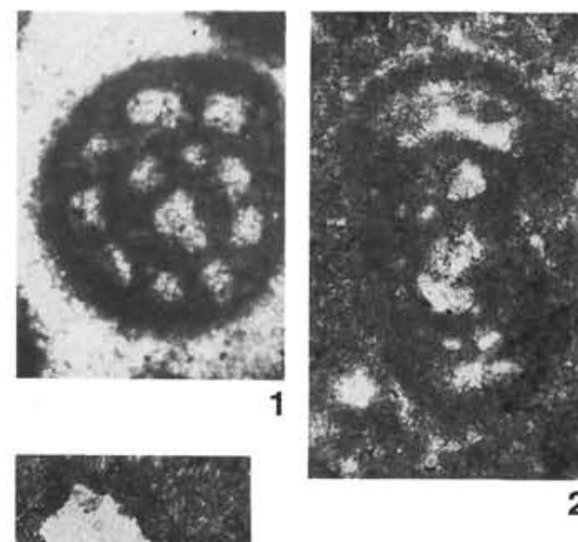

$100 \mu \mathrm{m}$

$200 \mu \mathrm{m}^{\star}$

$400 \mu \mathrm{m}^{\star \star}$
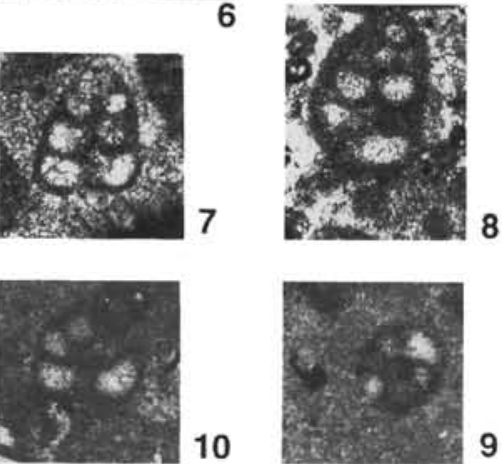

10
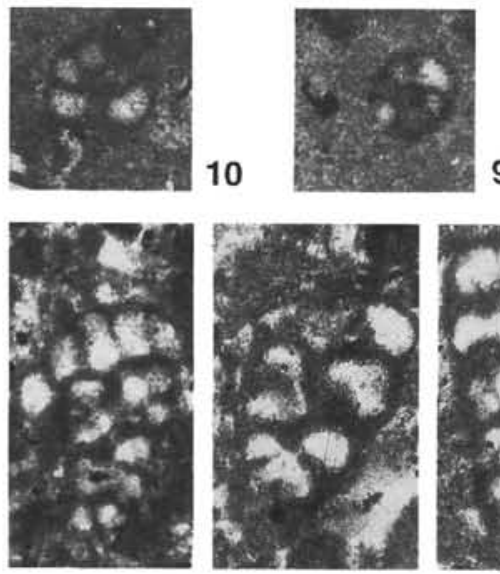

15

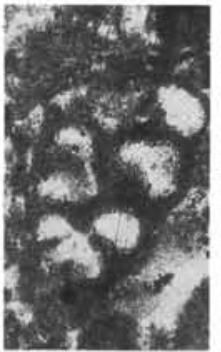

16

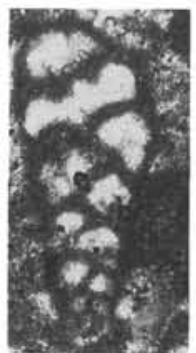

17
9
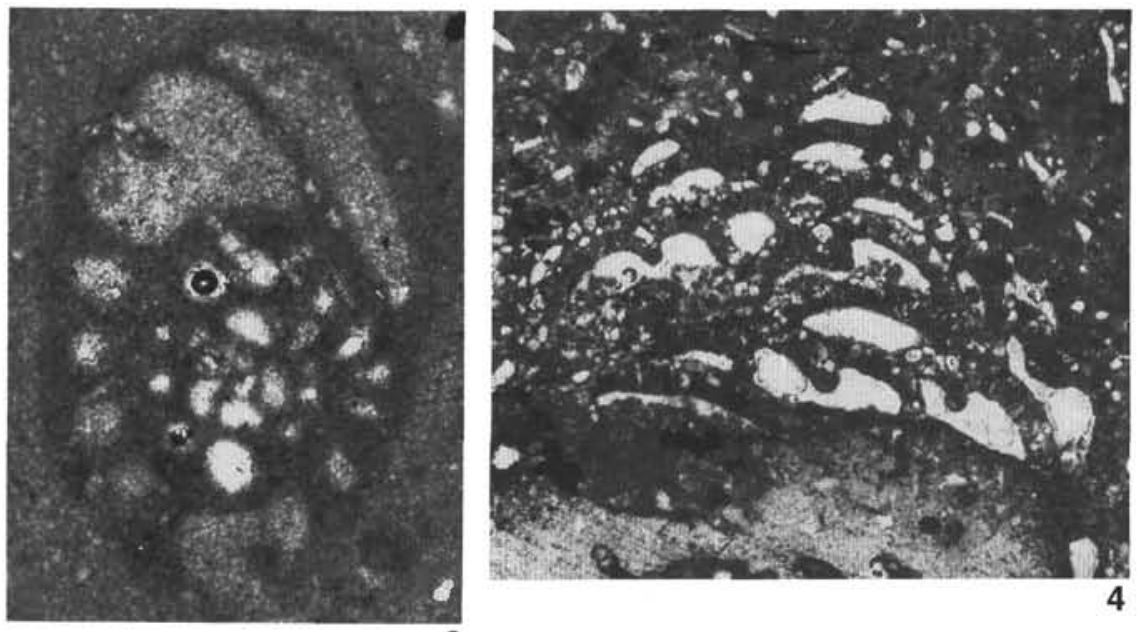

3

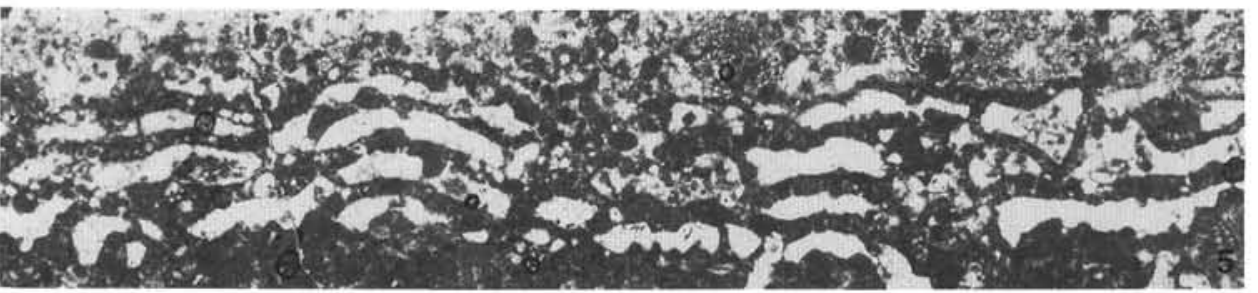

8
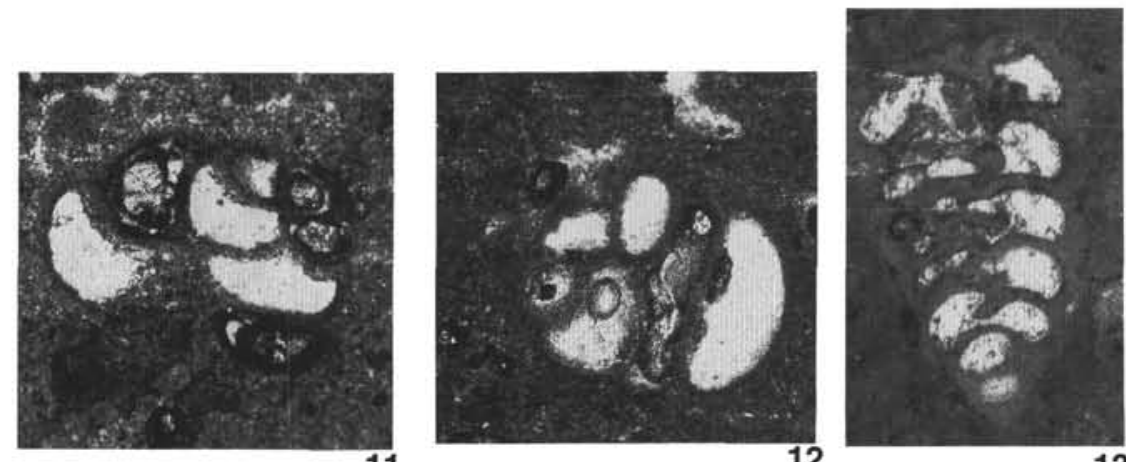

11

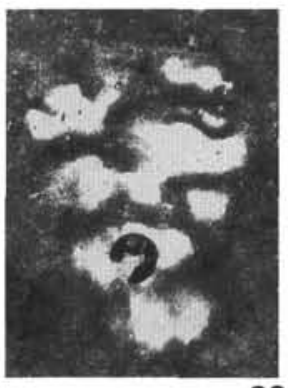

19

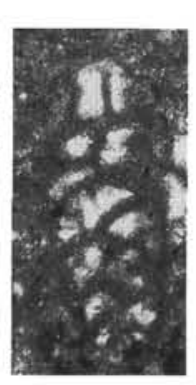

18

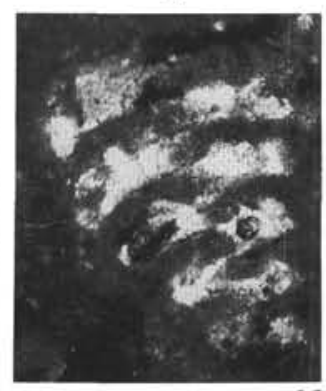

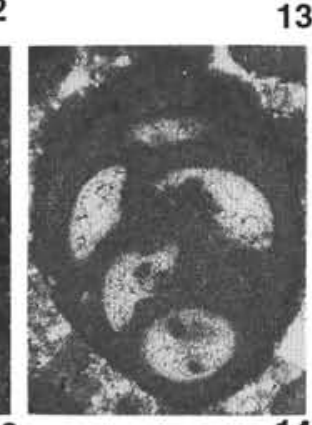

20

Plate 1. Benthic foraminifers of Leg 144. 1-2. Debarina sp. cf. Debarina hahounerensis; (1) Sample 144-879A-5R-1,82-87 cm; (2) Sample 144-878A-55R-2, 84-87 cm. 3. Daxia sp. cf. D. minima, Sample 144-879A-14R-1, 8-13 cm. **4-5. Bdelloidina sp. cf. Bdelloidina urgoniensis; (4) Sample 144-879A-3R-1, 42-43 cm; (5) Sample 144-878A-52R-2, 108-111 cm. 6. Ammobaculites celatus, Sample 144-878A-70R-1, 11-15 cm. 7-10. Arenobulimina sp. A.; (7) Sample 144-879A-16R-1, 131-135 cm; (8-9) Sample 144-879A-18R-1,22-26 cm; (10) Sample 144-879A-17R-1, 22-26 cm. 11-12. Arenobulimina sp. cf. A. chapmani; (11) Sample 144-878A-10R-1, 0-4 cm; (12) Sample 144-878A-12R-1, 24-28 cm. *13-14. Praechrysalidina sp. cf. P. infracretacea; (13) Sample 144-878A48R-1, 36-38 cm; (14) Sample 144-878A-57R-3, 134-137 cm. 15-18. Voloshinoides? sp. C; (15-17) Sample 144-878A-41M-1, 4-8 cm; (18) Sample 144-878A-35M-1, 2-6 cm. 19-20. Voloshinoides? sp. D; (19) Sample 144-878A-50R-2, 75-79 cm; (20) Sample 144-878A-70R-1, 54-57 cm. Specimen scale for samples with no label $=100 \mu \mathrm{m}$; specimen scale for single asterisk $\left(^{*}\right)=200 \mu \mathrm{m}$; specimen scale for double asterisks $(* *)=400 \mu \mathrm{m}$. 

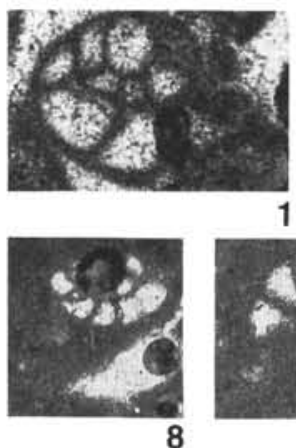

8

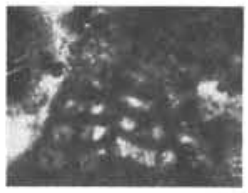

13

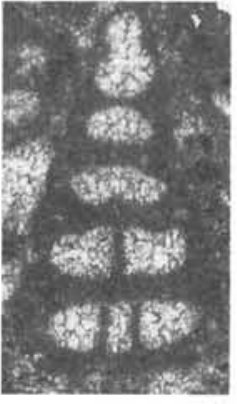

16

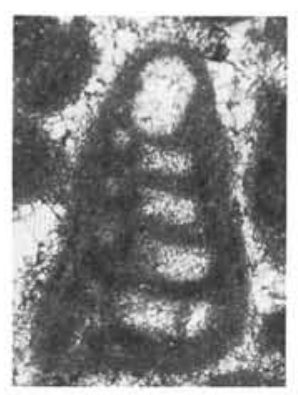

17

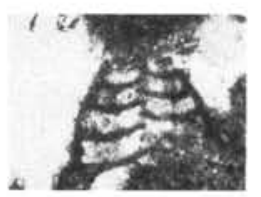

14
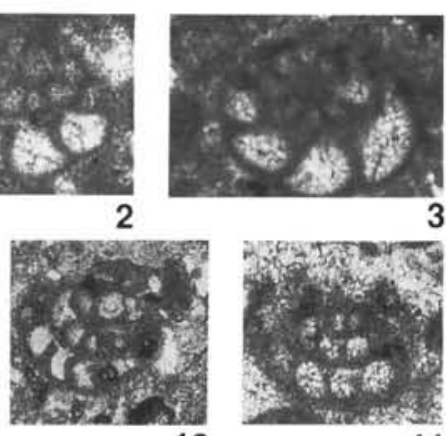

10

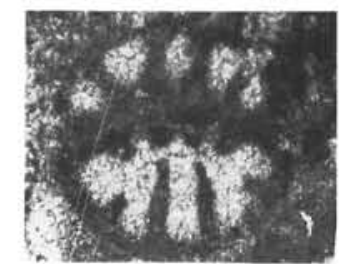

15

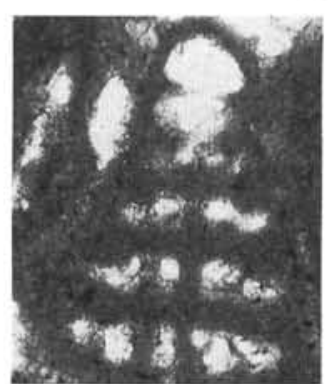

18

$100 \mu \mathrm{m}$

$200 \mu \mathrm{m}^{\star}$

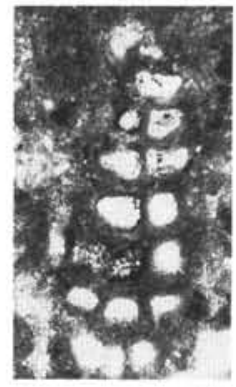

22

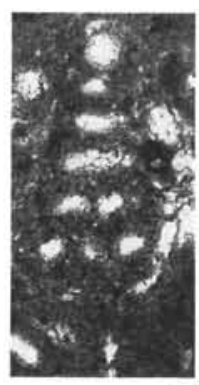

23

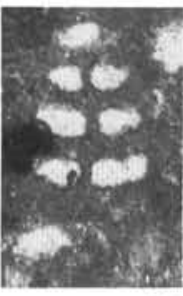

24

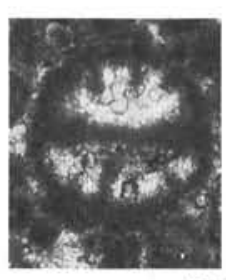

25

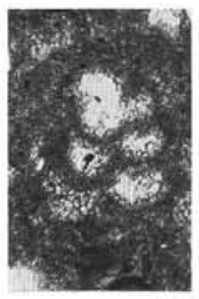

26

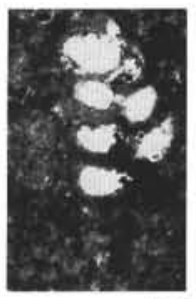

27

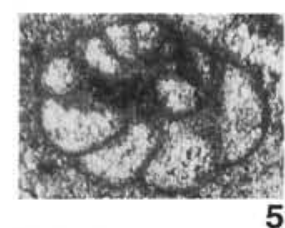

5

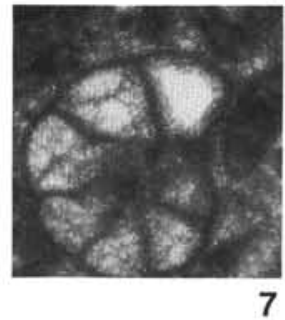

7
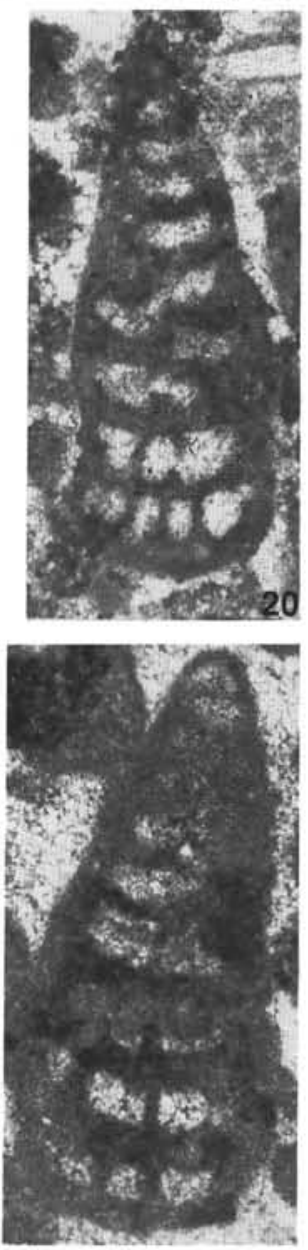

21

Plate 2. Benthic foraminifers of Leg 144. 1-3. Nezzazata isabellae; (1) Sample 144-879A-6R-1, 19-24 cm; (2) Sample 144-879A-5R-1, 31-37 cm; (3) Sample 144-879A-5R-1, 41-45 cm. 4-7. Nezzazata? sp C; (4) Sample 144-878A-55R-3, 46-49 cm; (5) Sample 144-878A-42R-1, 26-32 cm; (6) Sample 144-878A49R-1, 127-130 cm; (7) Sample 144-878A-74R-1, 6-10 cm. 8-9. Nezzazata sp. B, Sample 144-879A-17R-1, 0-5 cm. 10-12. Valvulineria? n. sp. 1; (10) Sample 144-878A-75R-1, 141-143 cm; (11) Sample 144-878A-74R-1, 6-10 cm; (12) Sample 144-878A-49R-1, 127-130 cm. 13-14. Sabaudia minuta; (13) Sample 144-878A-22M-1, 3-4 cm; (14) Sample 144-878A-22M-1, 0-4 cm. 15-18. Vercorsella sp. cf. V. arenata; (15-16) Sample 144-878A-4R-1, 52-54 cm; (17) Sample 144-878A-54R-2, 0-3 cm; (18) Sample 144-878A-57R-3, 134-137 cm. 19-21. Vercorsella sp. cf. V. scarsellai; (19) Sample 144-878A-8R-1,33-36 cm; (20) Sample 144-879A-5R-1, 60-64 cm; (21) Sample 144-879A-6R-1, 19-24 cm. 22-27. Vercorsella sp. cf. V. immaturata; (22-23) Sample 144-878A70R-1, 12-15 cm; (24) Sample 144-878A-70R-1, 11-15 cm; (25) Sample 144-878A-51R-2, 5-9 cm; (26) Sample 144-878A-74R-1, 6-10 cm; (27) Sample 144-878A-69R-1, $38-42 \mathrm{~cm}$. Scale $=100 \mu \mathrm{m}$. 

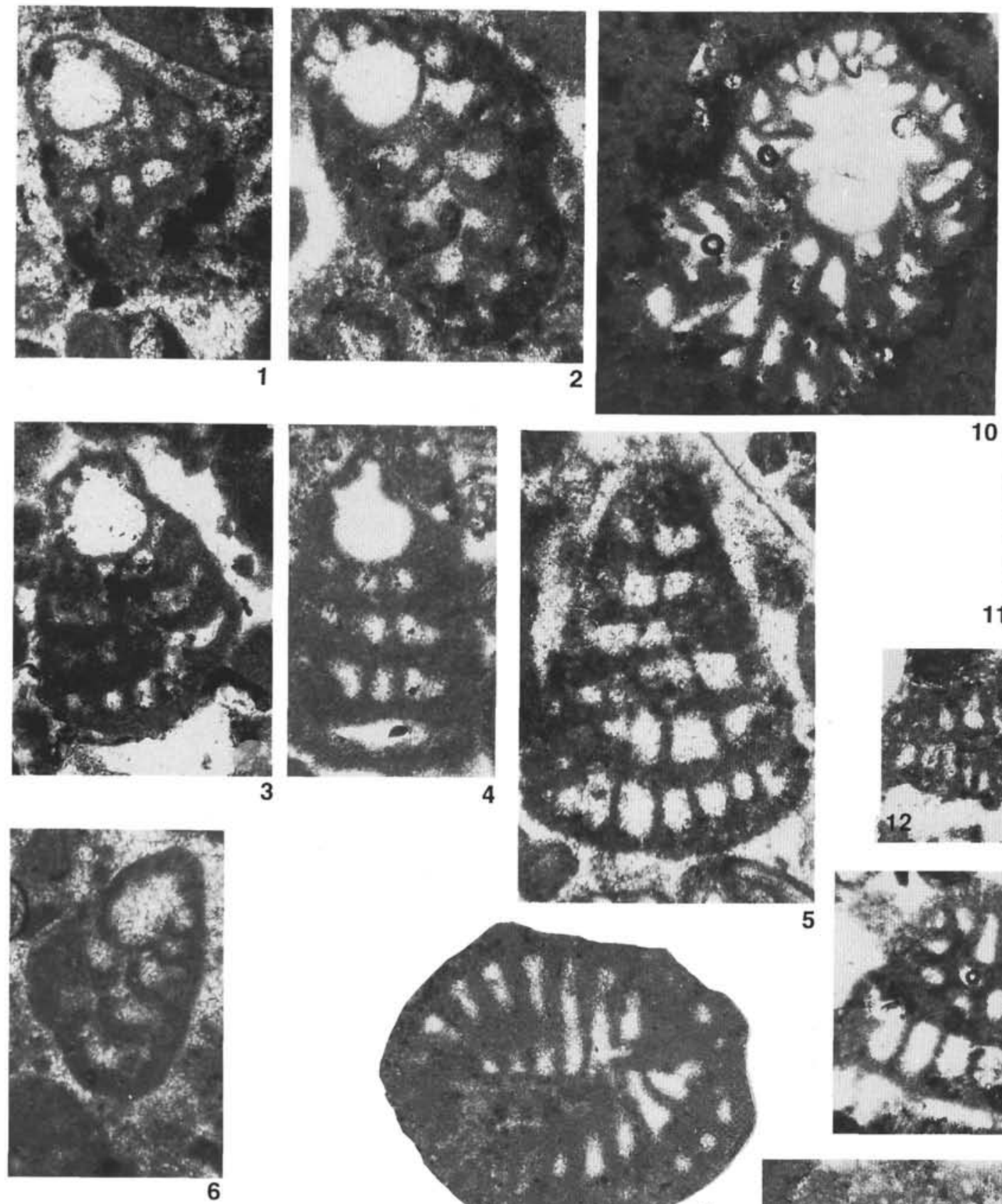

4

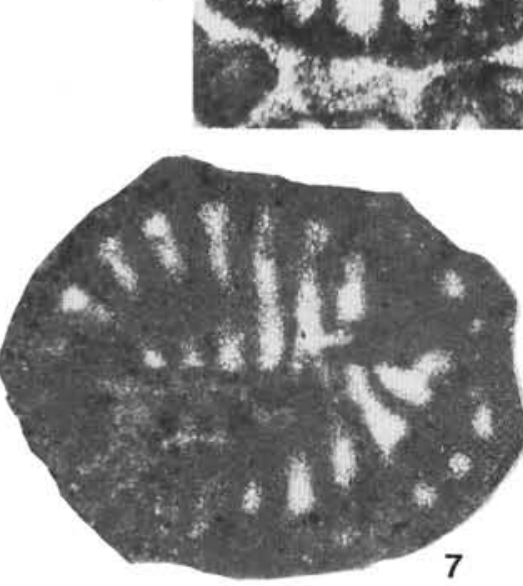

$100 \mu \mathrm{m}$

$200 \mu \mathrm{m}^{\star}$
10
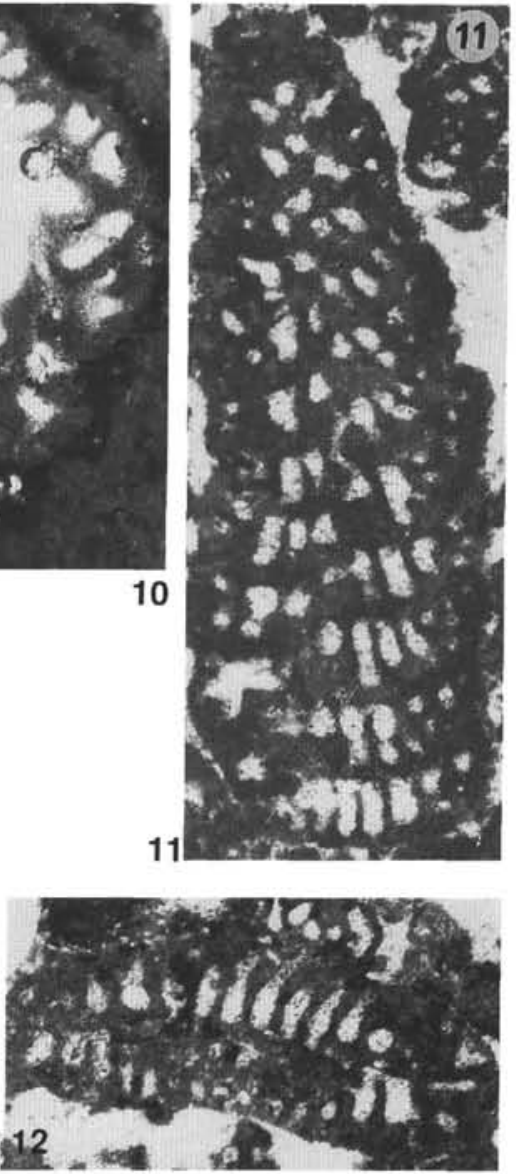

5
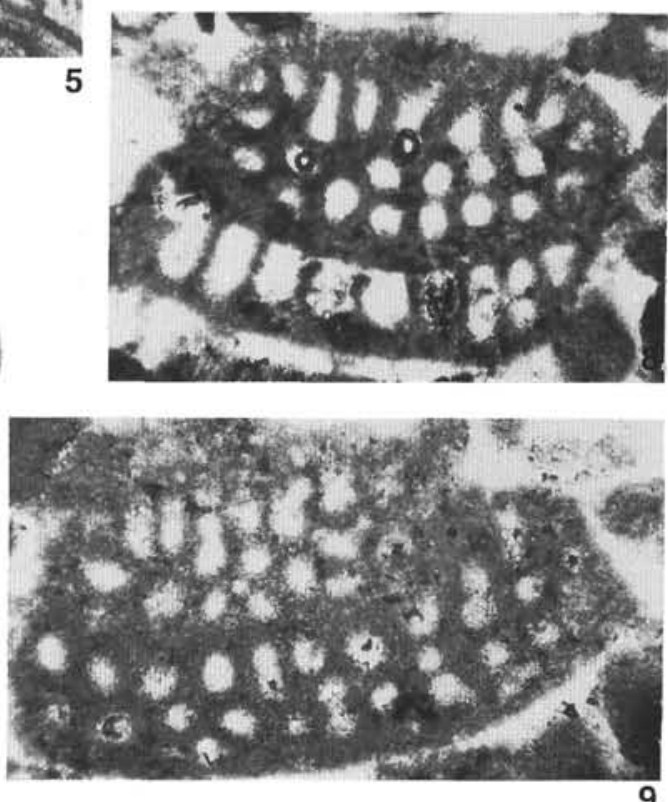

Plate 3. Benthic foraminifers of Leg 144. 1-9. Cuneolina sliteri $\mathrm{n}$. sp.; (1) holotype, Sample 144-879A-5R-1, 31-37 cm; (2, 5) Sample 144-879A-5R-1, 53-58 $\mathrm{cm} ;(3,8,9)$ Sample 144-878A-22M-1, 0-4 cm; (4) Sample 144-878A-22M-1, 0-4 cm; (6) Sample 144-879A-5R-1, 41-45 cm; (7) Sample 144-878A-23M-1, 22-25 cm. 10-12. Cuneolina sp. cf. C. pavonia; (10) Sample 144-878C-1R-1, 28-31 cm; *(11) Sample 144-879A-5R-1, 46-50 cm; *(12) Sample 144-879A$5 \mathrm{R}-1,31-37 \mathrm{~cm}$. Specimen scale for samples with no label $=100 \mu \mathrm{m}$; specimen scale for samples with single asterisk $\left({ }^{*}\right)=200 \mu \mathrm{m}$. 

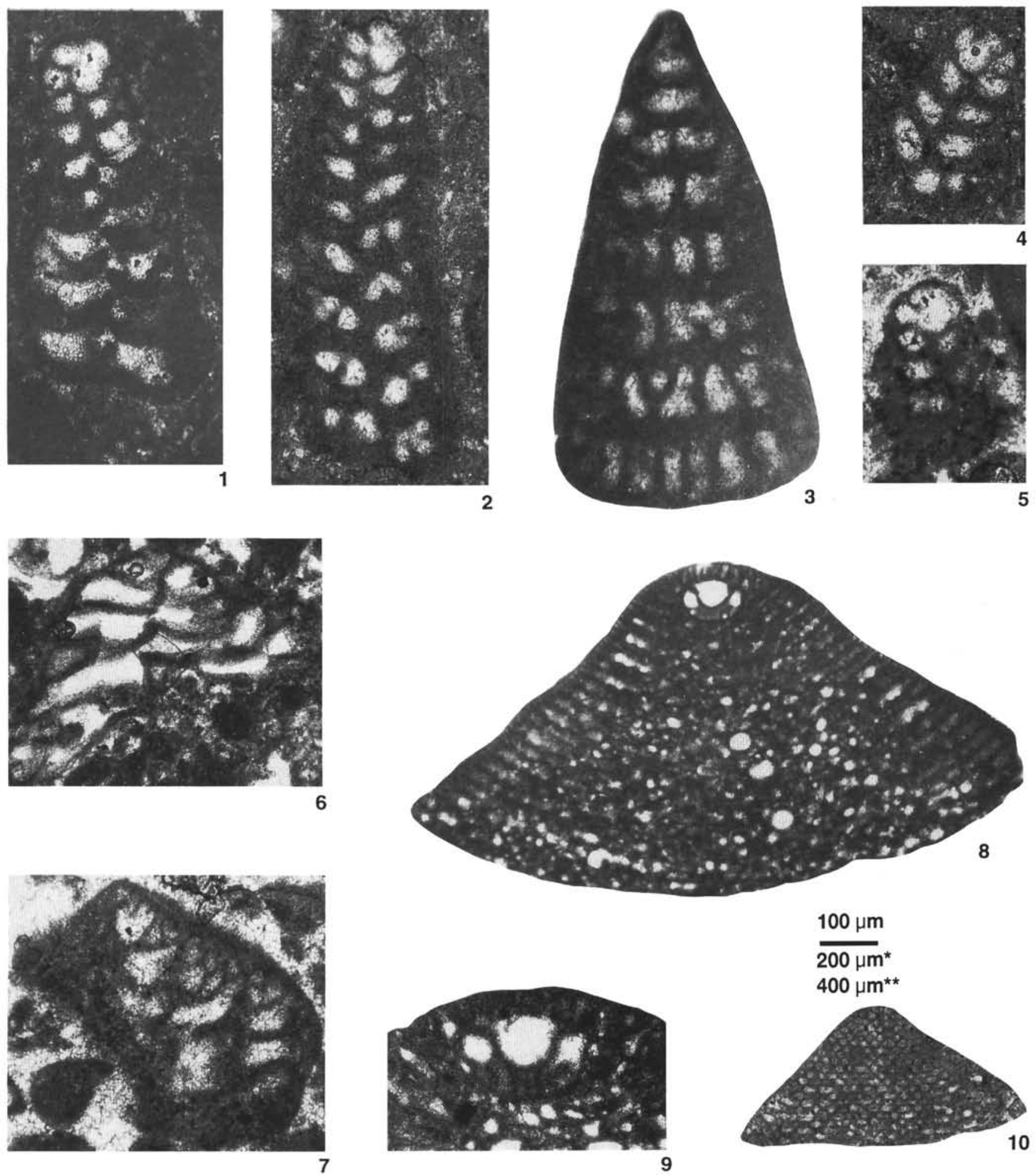

Plate 4. Benthic foraminifers of Leg 144. 1-5. Vercorsella sp. A; (1) Sample 144-879A-5R-1, 60-64 cm; (2) Sample 144-878A-60R-1, 129-132 cm; (3) Sample 144-878A-3R-1 (cuttings); (4) Sample 144-878A-3R-1, 59-61 cm; (5) Sample 144-879A-5R-1,41-45 cm. 6. Coskinolinella daguini, Sample 144-878A-41M-1, 4-8 cm. 7. Coskinolinella navarrensis, Sample 144-878A-31M-1, 4-8 cm. 8-9. Orbitolina (Mesorbitolina) texana oculata; *(8) Sample 144-878A-37R-1 (cuttings); (9) Sample 144-878A-30R-1 (cuttings). **10. Orbitolina (Mesorbitolina) sp. cf. O. (M.) pervia, Sample 144-878A-42M-1, 26-32 cm. Specimen scale for samples with no label $=100 \mu \mathrm{m}$; specimen scale for samples with single asterisk $(*)=200 \mu \mathrm{m}$; specimen scale for samples with double asterisks $(* *)=$ $400 \mu \mathrm{m}$. 

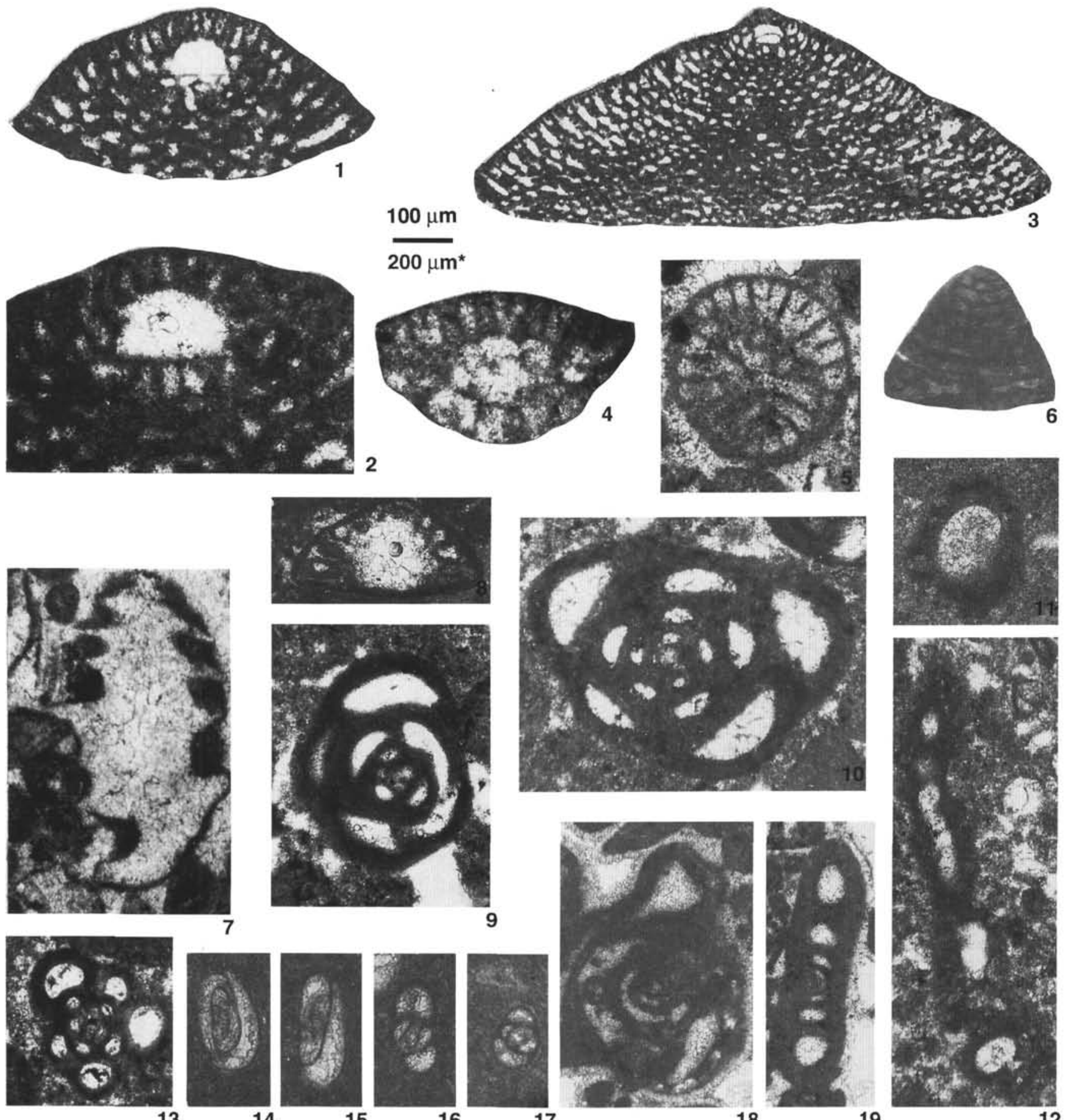

Plate 5. Benthic foraminifers of Leg 144. 1-2. Orbitolina (Conicorbitolina) sp. cf. O. (C.) aliensis; *(1) Sample 144-879A-5R-1, 60-64 cm; (2) Sample 144-879A-5R-1, 53-58 cm. 3-4. Orbitolina (Orbitolina) sp.; *(3) Sample 144-879A-5R-1, 46-50 cm; (4) Sample 144-879A-5R-1, 41-45 cm. 5-6. Paracoskinolina sp. cf. P. sunnilandensis; (5) Sample 144-879A-6R-1, 19-24 cm; *(6) Sample 144-879A-3R-1 (cuttings). 7. Trocholina altispira, Sample 144-879A-3R-1, 67-69 cm. *8. Trocholina sp. cf. T. odukpaniensis, Sample 144-879A-16R-1, 131-135 cm. 9. Pseudonummoloculina aurigerica, Sample 144-878A-23M-1, $22-25 \mathrm{~cm}$. 10. Rumanoloculina robusta, Sample 144-878A-45M-3, 123-125 cm. 11-12. Tubiphytes sp.; (11) Sample 144-878A-58R-1, 72-77 cm; (12) Sample 144-878A-60R-2, 23-27 cm. 13. Axiopolina? sp., Sample 144-879A-5R-1, 53-58 cm. 14-17. Istriloculina sp. cf. I. granumtrici, Sample 144-879A-15R-1, 35-37 cm. 18-19. Fischerina? carinata, Sample 144-879A-6R-1, 19-11 cm. Specimen scale for samples with no label $=100 \mu \mathrm{m}$; specimen scale for samples with single asterisk $(*)=200 \mu \mathrm{m}$. 